\title{
A Model for Assessing the Reuse of an Ancient Place of Performance: The Bouleuterion of Teos
}

\author{
Merve Çalışkan \\ Department of Architectural Restoration, Izmır Institute of Technology, Izmir, Turkey
}

\begin{abstract}
Ancient places of performance are often considered for reuse as a means of promoting archaeological sites. Therefore, local authorities and decision makers have a difficult task of balancing the conservation and management of the sites with the carrying capacity. In this paper, the bouleuterion, a'rediscovered'structure, at the Teos archaeological site, in Turkey is evaluated and presented as a preliminary case study with the hopes that these issues will be taken into consideration by the managing body in the creation of a management plan for the site. The evaluation is made by assessing socio-economic and intangible heritage significance, policies guiding changes at the site, a qualitative survey at the site and by defining the structure's carrying capacity. The site's strengths, weaknesses, opportunities, and threats are used to create criteria and make proposals for its reuse. The study concludes that the bouleuterion cannot be reused as a venue in its present condition and makes recommendations for future use.
\end{abstract}

\section{KEYWORDS}

Reuse; ancient places of performance; enhancement of ancient structures; management of archaeological sites; Teos archaeological site; carrying capacity

\section{History of the Site}

Teos archaeological site is located in Seferihisar, Izmir, Turkey and archaeological excavations have been carried out by Ankara University at the site since 2010. After these excavations began, there has been a call for increasing public awareness by local authorities for the promotion of Teos archaeological site. Evidence for this could be seen on billboards and local newspapers which declared the ancient city of Teos was the 'home' of Dionysian Arts and the bouleuterion (senate house) is going to be reused for public cultural events. ${ }^{1}$

There are several architectural remains at the site today and the most preserved structure at the site is the bouleuterion. It was built in the late third century BCE and used not only for political meetings, but also for rhetoric and musical performances in the late Hellenistic period (Gneisz 1990, 43). After excavations carried out at the cavea (the seating of the site) of the structure, the Municipality of Seferihisar organised several meetings and cultural events in the bouleuterion: a classical music concert in 2012; the meeting of villagers, and performance of poetry in 2013; which the author believes could be called pioneering events for the structure's future utilisation (Figures 1 and 2). 
The significance of ancient places of performance can be defined by four main issues: being ancient landmarks; impressive architecture; acoustic qualities; and use in modern cultural performances (Haddad 2007). The Verona Charter on the use of ancient places of performance (Council of Europe 1997, 373) claims that sites'such as theatres, amphitheatres and circuses are among the very few monuments still - in some cases - serving the purpose for which they were originally designed'. And that 'they form a heritage encompassing not only the monuments of Greco-Roman times but also the history of the alterations made to them, the successive uses to which they were put and the cultural and artistic traditions associated with them' (Council of Europe 1997, 373). The document further states 'the objective is to preserve a store of scientific information, manage the monuments in the perspective of development and, where circumstances permit, infuse ancient sites once more with their full role of places of artistic creation, shared enjoyment and emotion' (Council of Europe 1997, 373).

As seen at other sites in Turkey such as the theatres of Ephesus, Aspendos and Side, cultural events such as concerts, plays, or meetings have improved the sites' socio-economic value but according to the given examples their unplanned utilisation has caused decay and deterioration of these ancient structures (Aktüre 1995; Günday 2006; Öztürk 2006). The lack of management planning and uncontrolled growth of tourism are the most dangerous factors effecting these structures and their environment, where in some cases reconstruction has led to the loss of their integrity as authentic records of history. The original materials cannot be differentiated from the new ones and the ruined state

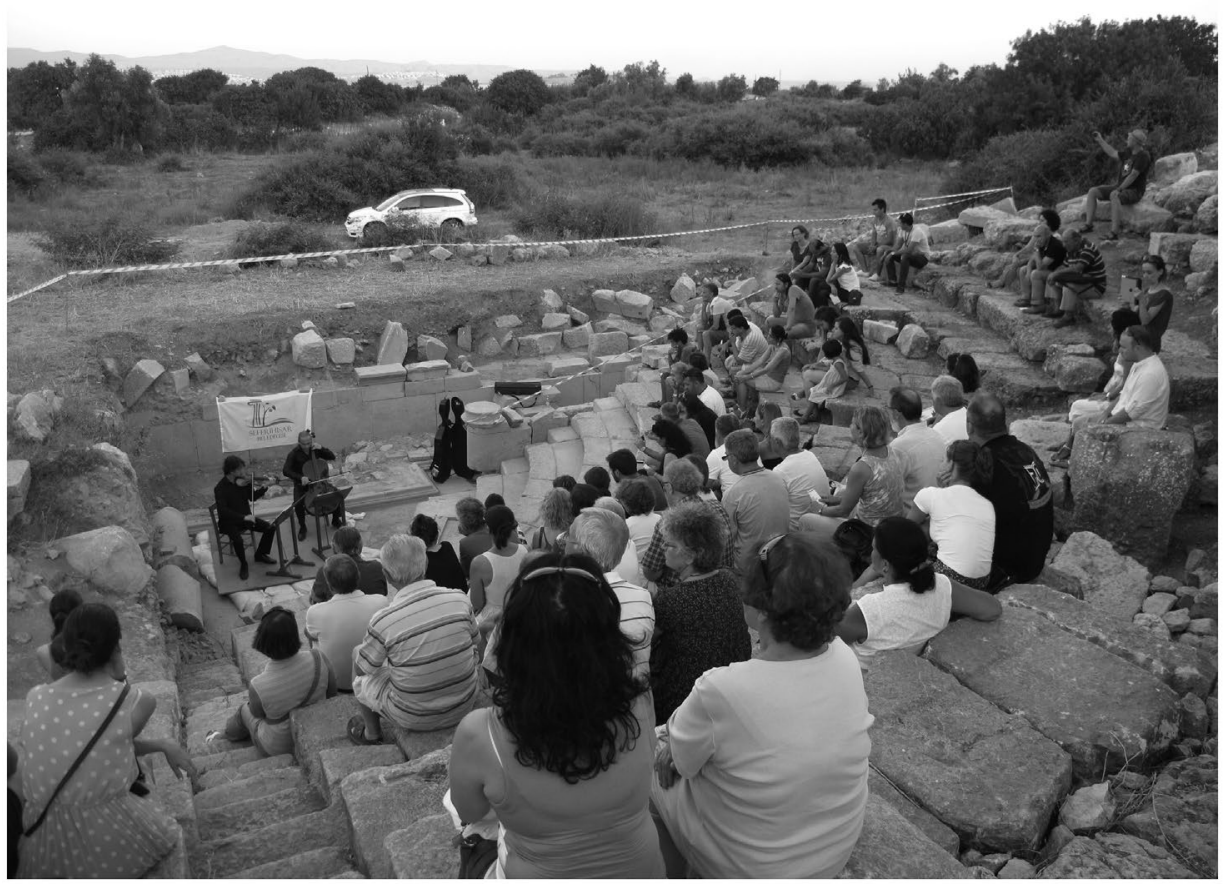

Figure 1. Classical music concert at the bouleuterion, 2012. Source: Teos Archaeological Project. Reprinted here by permission of Professor Dr Musa KADIOĞLU, Head of Teos Archaeological Project, Faculty of Languages, History and Geography, Department of Classical Archaeology, Ankara University. 


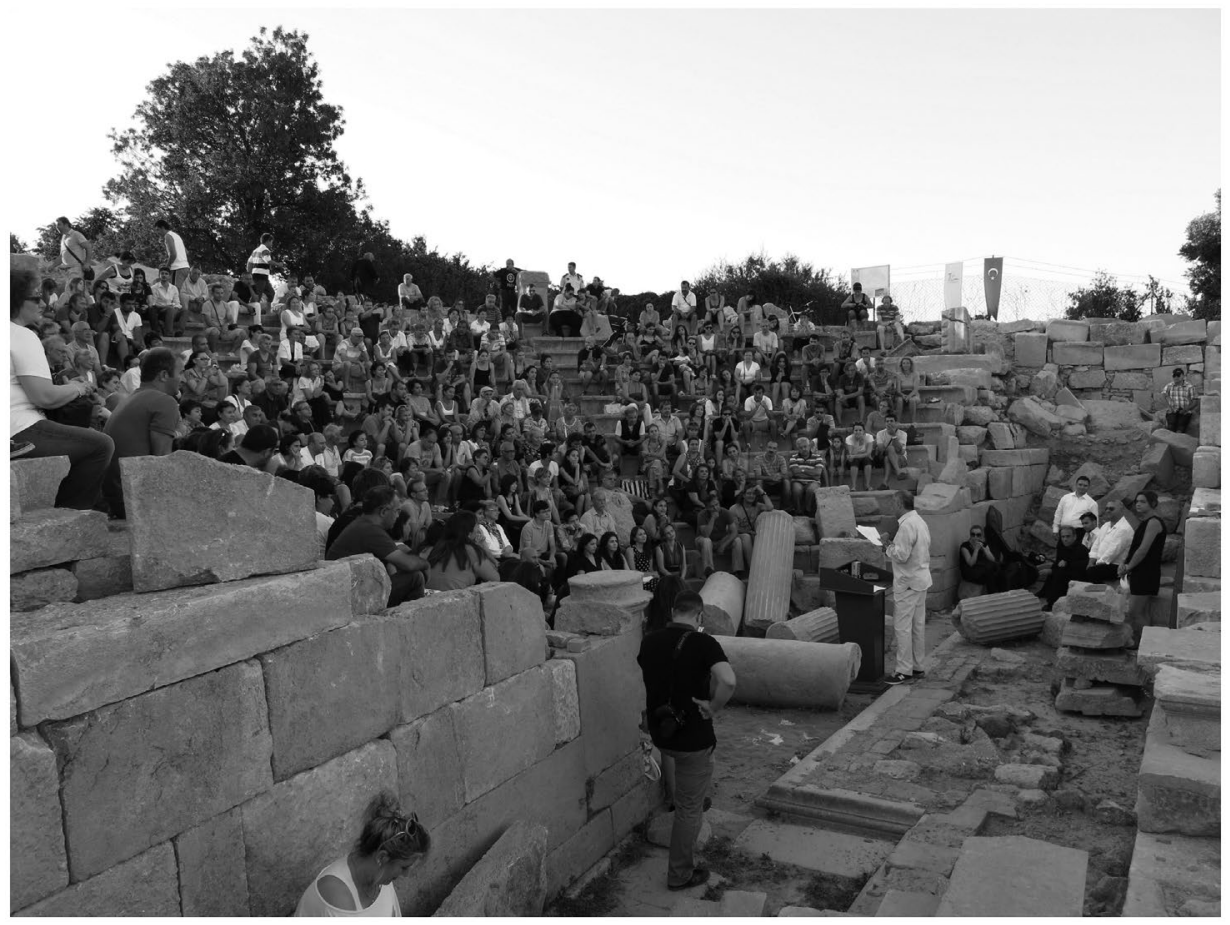

Figure 2. Performance of poetry at the bouleuterion, 2013. Source: Teos Archaeological Project. Reprinted here by permission of Professor Dr Musa KADIOĞLU, Head of Teos Archaeological Project, Faculty of Languages, History and Geography, Department of Classical Archaeology, Ankara University.

of the structures are lost in order to increase the seating capacity in the examples of the parliament building of Patara and the theatre of Metropolis. Actors such as the Ministry of Culture and Tourism, Directorate of Museums and Cultural Assets, Directorate of Archaeological Excavations, leaders of municipalities, etc. support utilisation to boost socio-economic development in their regions without understanding the long-term hazard to fragile sites. Excavation boards are asked to analyse the sites but not necessarily using scientific means. Furthermore, as the ruins belong to the ministry, the ministry may approve their utilisation without sound analysis which may cause long-term hazards for these unique structures which may result in the loss of cultural heritage. For example, in Sagalassos, the ministry continually wishes to use the theatre but the excavation board resists because it is not structurally sound. It is the conclusion of this paper that these sites would benefit from scientific research which enhances the sites' management in a controlled way.

For these purposes, the bouleuterion at the Teos archaeological site was chosen as a case study. It is part of an on-going excavation and is planned to be reused though a management plan is not yet extant. The aim of this study was to lay out the methods for determining whether a particular structure at a site could/should be reused. The author worked as the site architect documenting the bouleuterion between the years 2012 and 2013 with the aim of setting up a model for the building's future use to be presented to the relevant governing body. The study was presented to a jury at the author's university, a member of which was 
the head of the excavation team at Teos. Since then, excavations have ceased at the bouleuterion and have begun around the Dionysos temple and theatre. According to the Facebook page of the Municipality of Seferihisar, another concert with a small audience took place there during summer 2017.

\section{In Search of a Methodology: Assessing an Ancient Place of Performance}

Theoretically, a structure can resist static and dynamic loads while responding to use. In the case of historic buildings, the preservation of the site, its setting and physical environment should be considered (Feilden and Jokilehto 1993, 64). Ultimately, conserving historic buildings and sites as well as maintaining their role as cultural heritage depends on keeping them in use (Feilden 2003, 10). The ICOMOS (2003) Charter - Principles for the Analysis, Conservation and Structural Restoration of Architectural Heritage sets guidelines on how to conserve, preserve, and maintain the life cycles of historic buildings through three principles: general criteria to consider; researches and diagnosis; and remedial measures and controls. Additionally, the Australia ICOMOS (2013) Burra Charter focuses on the theory and practice of management in the planning process and is a distinctive document proposing a 'cycle' where the cultural significance is maintained and defines the actions of managers.

Altınöz, Güçhan, and Ayhan $(2011,13)$ delineate interventions from minimum to maximum as: 'monitoring; maintenance; consolidation; minor repair; repair; reinforcement-strengthening; rehabilitation; reuse-adaptive reuse; comprehensive repair; reintegration; replication; anastylosis; relocation and reconstruction' where intervention for ancient structures in a ruined state should comprise every means to understand the monument and reveal it without distorting its meaning (ICOMOS [1964] 1965, Article 15).

Ancient places of performance are also the subject of the Segesta Declaration (Council of Europe 1995); the Verona Charter on the use of ancient places of performance (1997), and the Syracuse Charter for the Conservation, Fruition and Management of the Ancient Theatrical Architectures $(2005,33)$ recommends:

- Organisation and Management of the knowledge of the conservation condition of the ancient theatrical architecture and their territorial context.

- Analysis, diagnosis, monitoring, conservation and restoration.

- Tolerable theatrical activities and safeguarding of the archaeological structure and its environmental context.

- Management of the ancient theatres and territorial cultural networks for local growth.

in order to manage the property in a scientific method approved by broad disciplines by the aim of enhancing ancient structures with their physical and social environment.

Beside the Charters and Declarations on ancient places of performance, MINOTEC, ${ }^{2}$ CHARISMA, $^{3}$ ERATO $^{4}$ THEATRON $^{5}$ and ATLAS $^{6}$ projects were generated on the acoustical properties of the ancient places of performance. The Euromed ATHENA (Ancient Theatres Enhancement for New Actualities) Project ${ }^{7}$ is a recent endeavour with the objectives:

- To minimise the progressive decay of ancient theatres in terms of physical, cultural and socio-economic aspects.

- To support the revival of theatres as a part of a wider archaeological site or urban context and 
- To establish an overall strategy for dealing with tangible and intangible heritage aspects.

The project includes branches of work packages and the Ancient Theatre Usage Manual is the output of the work package 4: setting up the management plan that aims to carry out the diagnostic phase and the subsequent action plans where information is provided on a particular theatre (Carbó et al. 2011, 120). The Ancient Theatre Usage Manual has three tasks to achieve; first is the collection of information for the development of preliminary activities, the second puts forward the aims: intrinsic actions and the third one collects the information needed for the development of cultural cluster informative system. A cultural cluster is defined as a cluster based on heritage sites that are the ancient theatres and 'is characterised by collecting in a territory a range of cultural activities, production and marketing of local handicrafts and farm products' (Carbó et al. 2013, 202). Therefore, in addition to the diagnostic study of physical aspects of the site, socio- economic aspects are also put forward in order to design future development strategies. It is a significant output that physical interventions are promoted by the social life and economy of the territory fed by artistic, local productions and tourism with regard to sustainability.

However, before a site can be used in a contemporary setting, its structural integrity must first be assessed. Only then should managers determine which contexts an ancient place of performance could or should be reused.

In this context, this study on the bouleuterion of Teos was carried out using an integrated methodology based on:

- ATHENA Project's cultural cluster informative system (Carbó et al. 2013, 220) categorised as 'Technical Aspects', 'Socio-economic and Intangible Aspects' (Carbó et al. 2013, 201) and 'Juridical Aspects' (Carbó et al. 2013, 273) to collect all the relevant data based on the current condition of the building and the region in order to define the bouleuterion's physical and real carrying capacity (Carbó et al. 2013, 269). Technical aspects include the evaluation of the physical condition of the building and the site whereas the socio-economical, intangible, and policy aspects are based on literature survey, legislation, reports on development, survey of visitors and interviews with stakeholders. The interviews included the head of Sığacık neighbourhood (muhtar in Turkish), the head of excavation board of Teos and the Mayor of Seferihisar, personnel from the Municipality of Seferihisar, Directorate of the Culture and Social works and two archaeologists from the Municipality of Seferihisar and Teos Archaeological Site. (See: Appendix B: Questionnaires for Stakeholders of Teos Archaeological Site, Çalışkan 2015, 267-284)

- The Burra Charter Process (ICOMOS 2013): to determine the cultural significance of the bouleuterion by conducting a SWOT Analysis in reference to the physical and real carrying capacity; to define criteria and proposals for reusing the bouleuterion as a preliminary study before creating a management plan of the site and the structure (Figure 3 ).

\section{Background and Archaeology of Teos}

Teos archaeological site is located on a peninsula in the Sığacık neighbourhood of Seferihisar, $60 \mathrm{~km}$ from İzmir, Turkey (Figure 4). The acropolis of the ancient city is located on Kocakır Hill, which is in the middle of the peninsula and the urban development of the ancient city could be observed between the Kocakır Hill and the southern port. The ancient city of Teos 

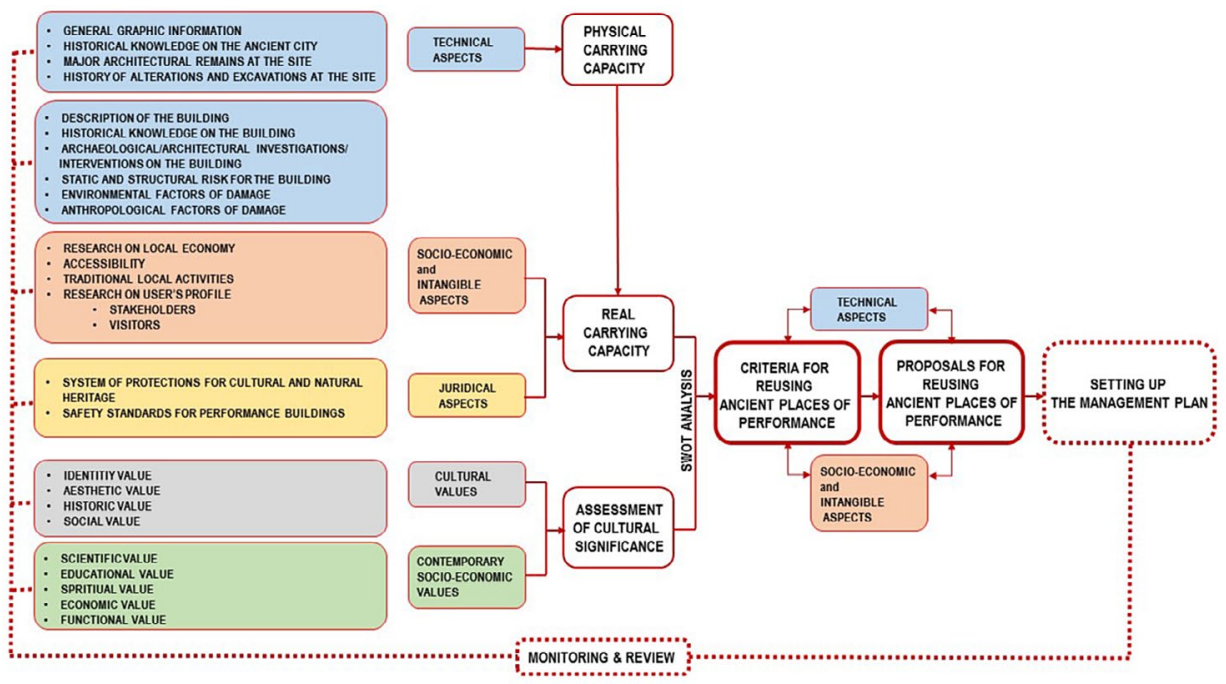

Figure 3. The model for reusing an ancient place of performance.
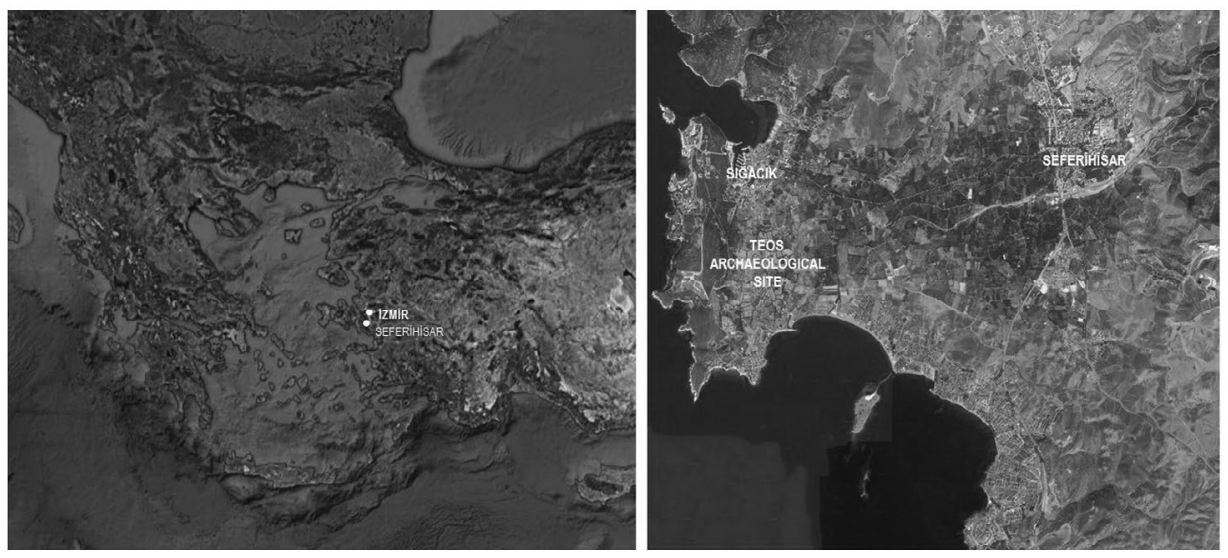

Figure 4. Location of Teos archaeological site. Source: Google maps.

is one of the twelve Ionian League cities with habitation from the Protogeometric Period (1050-900 BCE) to the Middle Ages and was an important harbour city with two ports located at its north and south (Akurgal 2014; Kadıoğlu et al. 2011). Most of the architectural remains belong to the Hellenistic and Roman Periods and the latest excavations reveal that the Hellenistic city walls are $4 \mathrm{~km}$ in length whereas the area of the inner city is thought to be 65 ha with the ancient structures inside such as acropolis, Temple of Dionysos, theatre, bouleuterion, agora, Agora Temple, and cistern. ${ }^{8}$ Two ancient ports and an imperial forum are located outside the Hellenistic city wall (Figure 5).

Teos was so wealthy around 600 BCE that Thales of Miletus suggested Teos be the capital of lonia (Akurgal 2014, 303). During the Hellenistic Period, the city was a major cultic centre, had the capability of resources for trading and founding of colonies in Abdera and Phanagoria, 


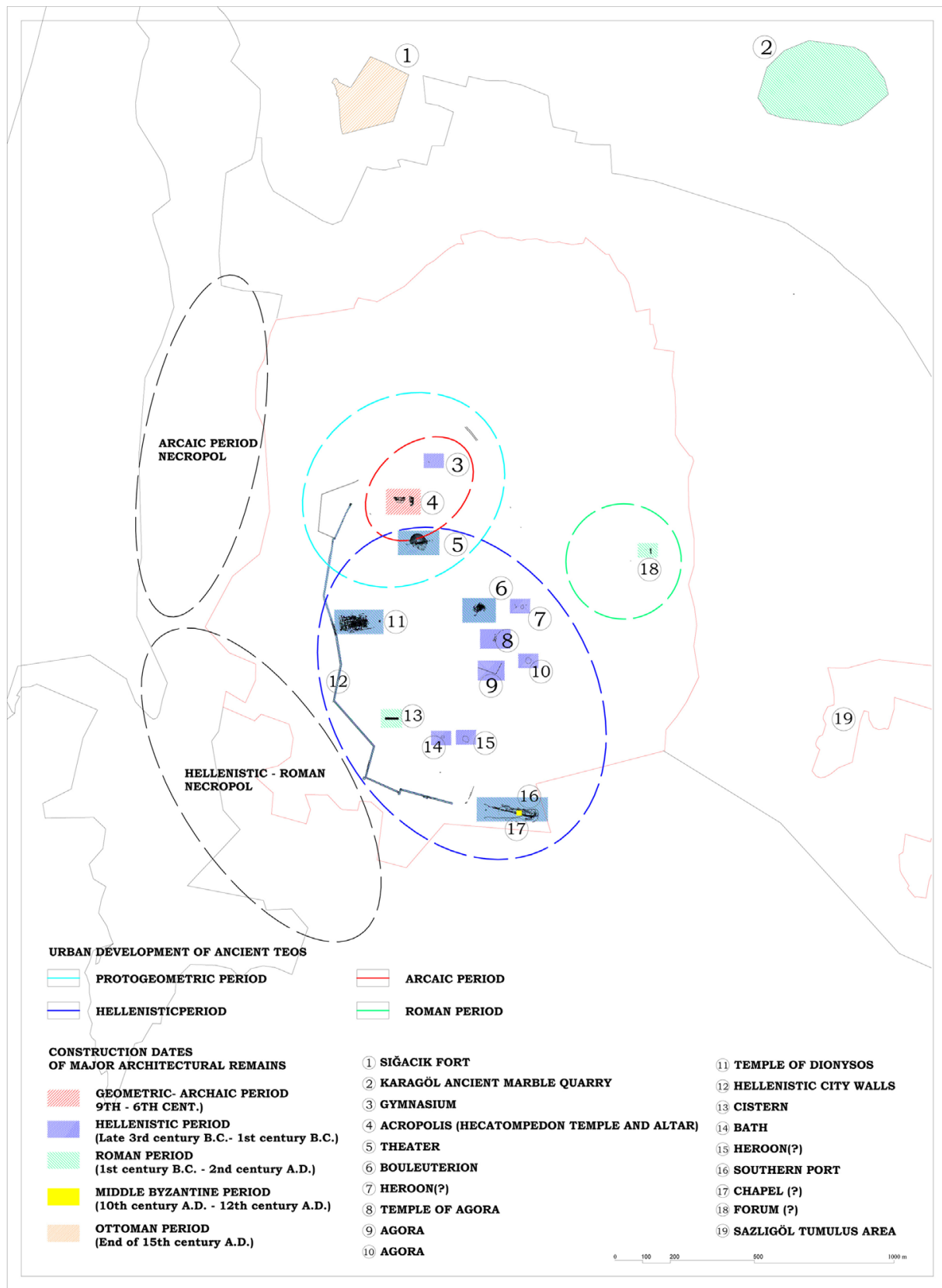

Figure 5. Ancient urban development of Teos.

and the Teans contributed 17 ships to the Battle of Lade in 494 BCE (Akurgal 2014, 303). In the period of Attalus I (reign date 241-197 BCE) Teos was part of the Pergamon Kingdom and after 129 BCE it was within the borders of Province of Asia - Asia Minor ruled by Romans. The Teans went on minting coins until the period of Valerian II when the city lost its importance, until the Middle Ages (Strang 2007, 92). 
'The principal deity of Teos was Dionysos' (Bean 1979, 107) and according to Vitruvius, the Temple of Dionysos was built by Hermogenes in around the third century BCE, which promoted the importance of the city in lonia (Akurgal 2014, 305). The Asiatic branch of Artists of Dionysos was founded in the city in the third century BCE and annual Dionysian cults and festivals increased the popularity of Teos as being the city of artists (Bean 1979, 107). In addition, Anacreon, Antimachus, Epicurus, Nausiphanes, Apellicon and the historian Hecateus were some of the important poets and philosophers who lived in Teos (Bean 1979, 109; Strabon 2000, 203; Akurgal 2014, 304).

Modern research on the ancient city of Teos began in the eighteenth century. The Society of Dilettanti showed an interest in the Temple of Dionysos, specifically R. Chandler and N. Revett were the first researchers who visited the site between 1764 and 1765 and R. Pullan conducted excavations at the Temple of Dionysos in 1862 (The Society of Dilettanti 1769, 1881). Between the years of 1924 and 1925, the French team of Y. Beguignon and A. Laumonier did research and carried out excavations at the Temple of Dionysos, Hellenistic city wall, agora and bouleuterion and they drew the ancient city plan for the first time (Béquignon and Laumonier 1925). Turkish archaeologists Y. Boysal and B. Ögün started to work at the site in 1962 and excavated the acropolis, agora, and theatre until 1967 (Ögün 1965). After that, Mustafa Uz worked at the site between the years of 1980 and 1992 and did further excavations at the Temple of Dionysos and an archaic temple known as 'hekatompedon temple' on the excavation report of 2014 and 2015 (Uz 1987). Between 1993 and 1996, Numan Tuna from Middle East Technical University conducted surveys and documented the territory of Teos (Tuna 1997). Since 2010, archaeological research has been led by Musa Kadıoğlu from Ankara University. ${ }^{9}$

\section{Current Situation at the Site}

Teos archaeological site is registered as an Immovable Tangible Property and is the treasure of the Turkish State ("Law on the Conservation of Cultural and Natural Property" 1983). Within the Teos archaeological site, there are first and third degree archaeological designations, urban conservation sites and first degree natural sites. ${ }^{10}$ The settlement of the ancient city is registered as first degree with an area of 110 hectares where construction is not allowed except for the facilities of service which are removable and light by the approval of the Directorate of Num. 1, Izmir Regional Conservation Council of the Ministry of Culture and Tourism, the General Directorate of Cultural Properties and Museums. The first degree archaeological site is surrounded by the third degree archaeological and first degree natural sites and in the third degree, all of the construction works, including infrastructure, are limited and must be approved by the Directorate of the Museum of Izmir, by the Director of Cultural Assets and Museums, and the Regional Council of Conservation by the Ministry of Culture and Tourism. A personnel from the Directorate of the Museum of Izmir is sent to control the construction works in third degree archaeological sites; they drill from ground level in some parts to determine whether there is a cultural layer beneath, in cases where there is no cultural layer it is confirmed by the personnel and the regional conservation council gives permission for the new construction. In these cases, there are two bodies for the approval. The Urban Conservation Site where the northern port of the ancient city is located is in Sığacık neighbourhood and is an historic urban settlement inside the fortress used by the Seleucids and Ottomans (Kahraman 2011). Before the sites were registered and protected, there were construction works: residential and touristic edifices were built near the western and southern 
Hellenistic city wall and were probably built on the Necropolis of the Ancient City in the late 1980s. Rescue excavations (Kadıoğlu et al. 2011,449) were carried out on the west and south necropolis where the pathway leads to the summer houses on the south. There is a huge hotel construction in the third degree archaeological site on the west of the Hellenistic walls and here excavations are controlled by the directorate of the museum. Summer houses on the south were built in the 1980s, however at that time the site was not registered which means that there was no control/protection mechanism for new construction. Thus, the area of summer houses located on the west of Teos (outside the Hellenistic city walls) is not registered whereas on the west coast of the peninsula, touristic facilities are in the middle of being constructed and are controlled by the Directorate of the Museum of Izmir.

Teos archaeological site, located inside the borders of the Municipality of Seferihisar, has gained importance as a catalyst to increased tourism. Seferihisar is listed by the CittaSlow Network, ${ }^{11}$ part of the Slow Movement which is concerned with slowing the pace of life and with Slow Food ${ }^{12}$ in particular. Therefore, the municipality of Seferihisar has shown interest in the Teos archaeological site as an aspect of appreciating local authenticity. To this end, the municipality as well as the governor of Seferihisar and Ministry of Cultural Assets and Tourism have financed archaeological research at the site. Additionally, a project called 'the conservation of Teos Wetland area and its dunes' has been prepared by the Association for the support of Slow Life, ${ }^{13}$ the municipality, ${ }^{14}$ and the Association of Nature ${ }^{15}$ with the support of GEF Small Grants Programme (SGP) where brochures were published in order to inform the public about the flora and fauna of the archaeological site and its surroundings. ${ }^{16}$ Information boards about the olive and mandarin trees, mammals, the ancient harbour, flora around the agora, and birds around the bouleuterion were placed along the paths (Figure 6).

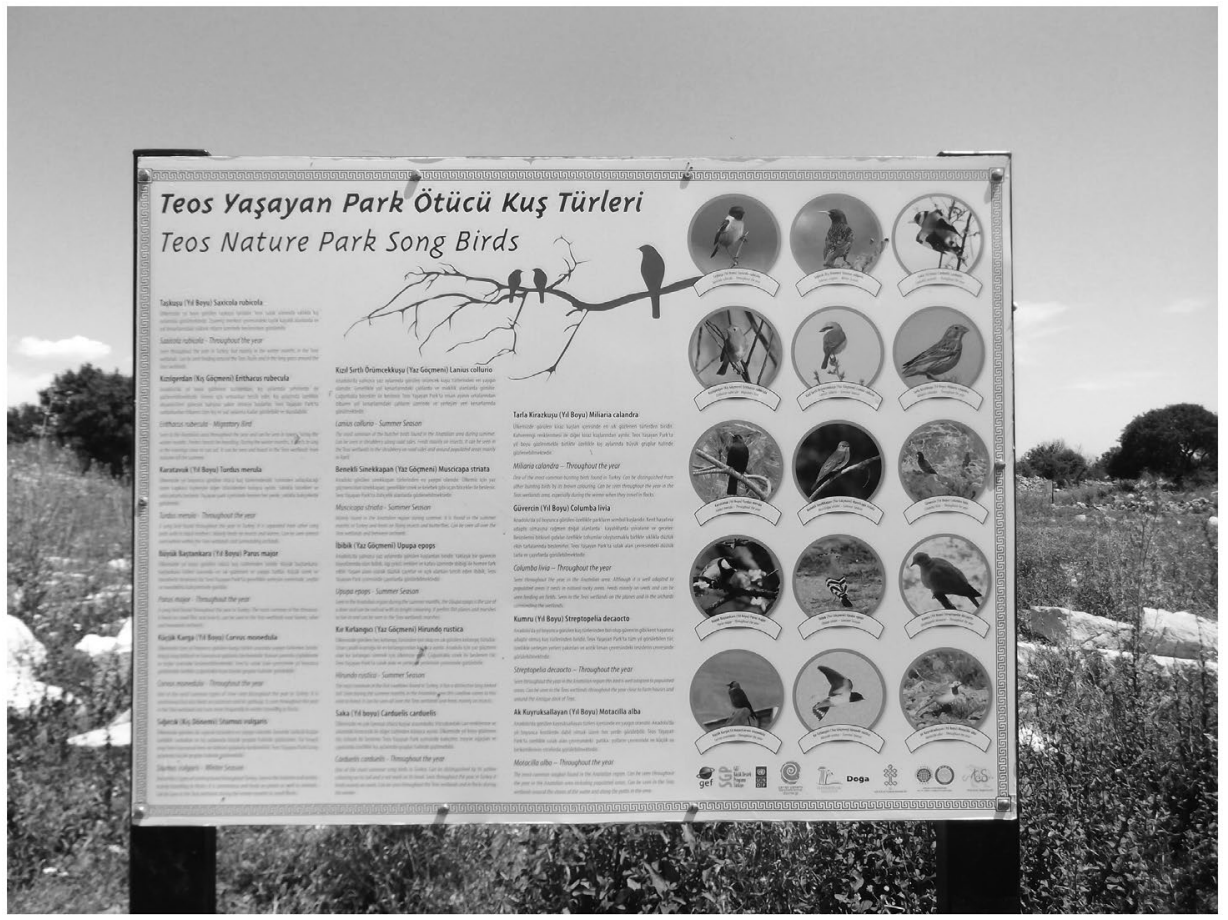

Figure 6. Info board of Teos Wetland area and its dune. 
The landscaping project of Teos Archaeological Site was approved by the decision of Directorate of Num. 1, Izmir Regional Conservation Council in 2012. Two buildings were designed on the west of first degree archaeological area on the same parcel; the entrance building with museum/workshop for restoration, information centre, café, ticket office and restrooms and excavation house were designed as separate buildings. After drilling and geophysical research was completed, the construction started in 2013 and completed in 2015 (Kadıoğlu 2015, 452; Kadıoglu et al. 2017, 486). Within the scope of the project, circulation and access routes were designed in three types that are long, middle and short tours. The long route starts from the entrance building passing through the main architectural remains located in the core of the ancient city. The middle route includes Dionysos Temple, Agora, Bouleuterion and Theatre and the short-route has only Dionysos Temple. In addition, a tour for cyclists was proposed being the length of $4.3 \mathrm{~km}$ starting at the Ancient Marble Quarry in Karagöl and finishing at the site entrance. In addition, spots to take a break near the major architectural remains were designed with equipment including banks and rubbish bins and info boards with a descriptive text and drawings were placed near the major remains. For the guidance of visitors, signboards were placed on the routes.

In this study, evaluation of the Teos archaeological site was made in 2014 with the main categories being: equipment; resources; internal and; external services (Figure 7). The entrance building was built in 2014 and has an information point with coffee shop, toilets, a ticket office and exhibition hall. In 2016, the Ministry of Culture and Tourism created a position for the ticket office and toilets. The exhibition hall is in use today whereas the coffee and gift shop have not been opened. Official tourist guidebooks and a website are available as internal services whereas the external parking, public transportation, and accommodation are in progress as external services. ${ }^{17}$ Equipment at the site is also in progress including lighting, rubbish collection, access, security system, handrails, signs and measures for fire prevention. Since the core of the site is about 65 hectares and there are some parcels belonging to private owners in this area, access between ancient structures is problematic in some parts and the expropriation of these parcels has become contested. There are private parcels at the site; the landscaping project (pathways, benches etc.) was prepared according to the current situation. Legally, public access can be hampered in these private lands but since the owners are not allowed to construct and cultivate, these lands are left and people can pass through them as a short cut. As far as the author is aware, some local people complain about the situation that they cannot use and sell their land and the only option is to expropriate the lands; in addition in some cases, the owners have raised their asking price which has resulted in delays. As a cultural cluster (Carbó et al. 2013, 202) Sığacık is a distinct area, just $4.1 \mathrm{~km}$ from the archaeological site, and where the visitors might find any service, local products, and might experience gastronomical facilities that provide economic resources for the area's socio-economic development (Figure 8).

\section{The Survey}

In order to understand the effectiveness of the resources, a qualitative survey was conducted; the questionnaires were broken down into four subjects: the user's profile, accessibility, knowledge, and utilisation and a survey of 50 people was conducted in August 2014 (Figures 9 and 10). The results showed that the visitors get information about access to the site and its historical significance from the media and the Internet, with academic journals and 


\begin{tabular}{|c|c|c|}
\hline EQUIPMENTS & Presence $(\mathrm{Y} / \mathrm{N})$ & Explanation \\
\hline LIGHTING & $\mathrm{Y}$ & $\begin{array}{l}\text { There is only power line that reaches next to Dionysus Temple. } \\
\text { There is no permanent lighting devices on the site }\end{array}$ \\
\hline RUBBISH-LITTER & Y & $\begin{array}{l}\text { There are rubbish bins at each rest point } \\
\text { There are benches at each rest point }\end{array}$ \\
\hline ACCESS & Y & $\begin{array}{l}\text { There is a cadastral pathway on the site that starts from the site } \\
\text { entrance to Acropolis, Temple of Dionysos, Theater, Bouleuterion } \\
\text { and Agora }\end{array}$ \\
\hline SECURITY SYSTEMS & $\mathrm{N}$ & - \\
\hline DEFENSIVE STRUCTURES & Y & There are handrails in Bouleuterion \\
\hline SIGNAGE \& SIGNS & Y & $\begin{array}{l}\text { There are information boards at each architectural remain. } \\
\text { Historical/Architectural Info is given with plans }\end{array}$ \\
\hline $\begin{array}{l}\text { MEASUREMENTS FOR FIRE } \\
\text { PREVENTION }\end{array}$ & $\mathrm{N}$ & There is no permanent fire extinguisher at the site \\
\hline RESOURCES & Presence $(\mathrm{Y} / \mathrm{N})$ & Explanation \\
\hline INFORMATION POINT & $\mathrm{N}$ & is under construction \\
\hline BOOKSHOP & $\mathrm{N}$ & is not present in the current project \\
\hline BARS\&COFFEE SHOPS & $\mathrm{N}$ & is under construction \\
\hline TOILETS & $\mathrm{N}$ & is under construction (for 2 women +2 men) \\
\hline TICKET OFFICE & $\mathrm{N}$ & is under construction \\
\hline INFIRMARY & $\mathrm{N}$ & is not present in the current project \\
\hline EXHIBITION HALL & $\mathrm{N}$ & is under construction \\
\hline INTERNAL SERVICES & Presence $(\mathrm{Y} / \mathrm{N})$ & Explanation \\
\hline OFFICIAL TOURIST GUIDES (STAFF) & $\mathrm{N}$ & - \\
\hline OFFICIAL TOURIST GUIDEBOOKS & Y & $\begin{array}{l}\text { The guidebook is written in Turkish and English for the generic } \\
\text { visitors }\end{array}$ \\
\hline AUDIO GUIDES & $\mathrm{N}$ & - \\
\hline TELEMATIC RESOURCES & Y & See the website: www.teosarkeoloji.com \\
\hline EXTERNAL SERVICES & Presence $(\mathrm{Y} / \mathrm{N})$ & Explanation \\
\hline EXTERNAL PARKING & Y & $\begin{array}{l}\text { Parking lots are located on the site entrance for } 22 \text { cars and } 4 \\
\text { buses }\end{array}$ \\
\hline PUBLIC TRANSPORTATION & Y & $\begin{array}{l}\text { The access to the site can be done by taking a bus(dolmuş) from } \\
\text { Seferihisar/Sığacık which stops in } 500 \text { meters distance to the site } \\
\text { entrance } \\
\text { There is no public bus }\end{array}$ \\
\hline ACCOMODATION\&RESTAURANTS & Y & $\begin{array}{l}\text { In SIğacik neighbourhood, there are tourism facilities \& } \\
\text { restaurants (see IZKA report) }\end{array}$ \\
\hline
\end{tabular}

Figure 7. Chart on the evaluation of Teos archaeological site.

advertising signs also significant sources of information. Since there is no direct public transportation to the site entrance, private cars are the main means of transportation. Most of those surveyed think that the site is not compatible with traditional festivals such as the mandarin festival that is held in Seferihisar every year. In addition, of those surveyed, 78\% visited other archaeological sites, which can be interpreted to mean that they are generally interested in archaeological sites in the region. Most of those surveyed are in the age range of 19-30. This is encouraging for increasing the opportunities at the site to share knowledge, to raise consciousness about the cultural heritage of Seferihisar, and to improve the quality 


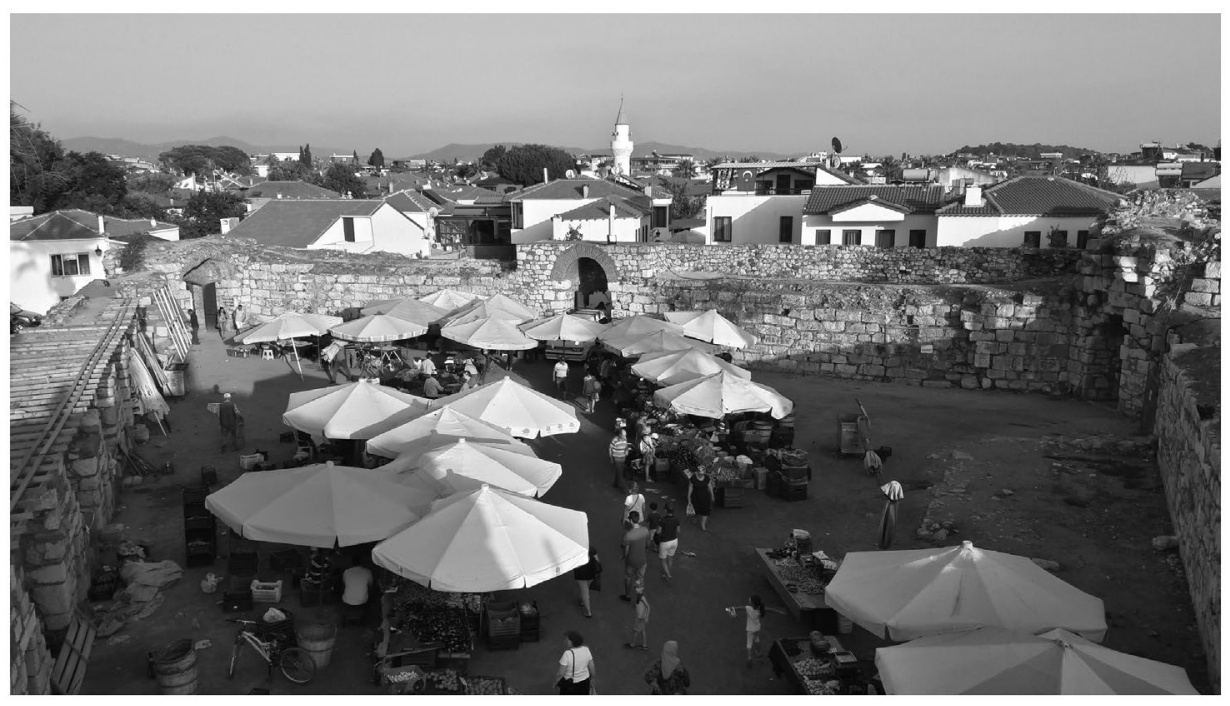

Figure 8. Sığacık Fort.

of visitor's experiences. It should be noted that the survey was carried out at the same time construction works were being done and this hampered a more comprehensive study (Çalışkan 2015).

\section{The Bouleuterion}

The bouleuterion is located to the south-east of the theatre, north-west of the agora temple, and east of the Temple of Dionysos and is the most well preserved ancient structure in Teos (Kadıoğlu et al. 2011, 433) (See Figure 11). It was built on flat ground and has a rectangular plan of $33.25 \mathrm{~m} \times 21.8 \mathrm{~m}$, with semi-circular shaped seating (cavea). The building was researched by a French excavation team in 1924 first; the upper part of the cavea was unearthed and the building was defined as a small theatre (Béquignon and Laumonier 1925). Bean $(1979,113)$ determined that the building was an odeon (space for performances) with two statue bases with inscriptions in honour of distinguished citizens of Teos in the Roman Era. The bouleuterion was then excavated by Y. Boysal and B. Öğün in 1963 and1964 (Öğün 1965); Tuna (1997) conducted further research and the building was ultimately confirmed to be a bouleuterion (a senate house) where the measured drawings were made between 1993 and 1995. Since 2010, excavations at the building have been carried out by Kadıoglu et al. $(2011,2013,2016,2017)$ and Kadıoğlu (2015) (Figure 12).

The building, with the exception of the northern wall, has been unearthed. It has two entrances and is made up of three parts: the cavea (seating), orchestra pit, and pulpitum (stage). The plan of the building, which dates back to the first century BCE shows that the bouleuterion had 18 seating rows with a capacity of 634 people (calculated as seating area $/ 0.50 \mathrm{~m}^{2}$ ) and it is possible that there were stairs next to the northern and southern walls (Figure 13). The main walls of the building were constructed in a rectangular pseudo-isodomic technique as hollow dry stone walls. There are additions built later using spolia, rubble stones and mortar were used to construct the pillars on the south-west corner, on the 


\section{USERS'PROFILE}

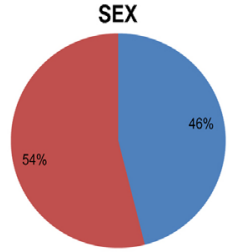

- MEN $\quad$ WOMEN

LEVEL OF EDUCATION

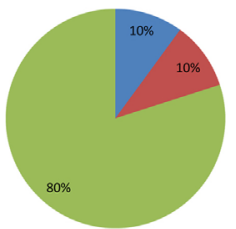

ELEMENTARY SCHOOL - HIGH SCHOOL - UNIVERSITY

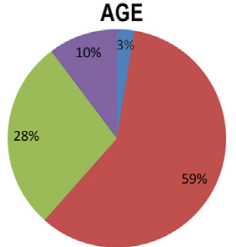

a11-18 $\square 19-30$ $\square 31-50 \square 51-65$

-STUDENT $\square$ UNEMPLOYED 口EMPLOYED $\square$ RETIRED

HAVE YOU EVER VISITED ANY OTHER ARCHAEOLOGICAL SITE IN THE REGION?

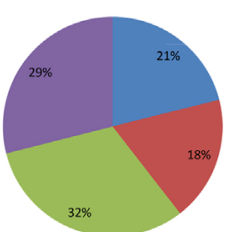

-INDIVIDUAL $\square$ SMALL GROUP -COUPLE FAMILY

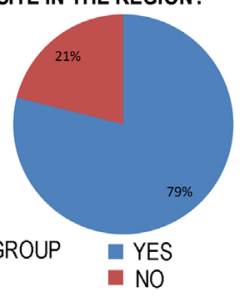

\section{ACCESSIBILITY}

DO YOU THINK THAT DO YOU THINK THAT BOULEUTERION TEOS ARCHAEOLOGICAL SITE IS EASILY ACCESSIBLE IS EASILY ACCESSIBLE? AT THE SITE?
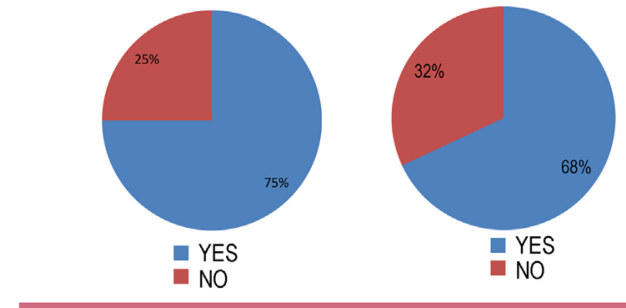

WHICH MEANS OF TRANSPORTATION

DID YOU USE FOR ACCESS

TO TEOS ARCHAEOLOGICAL SITE?

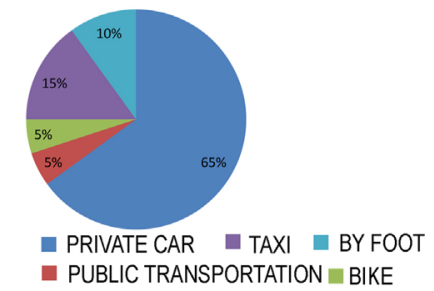

INFORMATION\&KNOWLEDGE

DID YOU GET INFORMATION ABOUT THE SITE BEFORE YOUR VISIT?
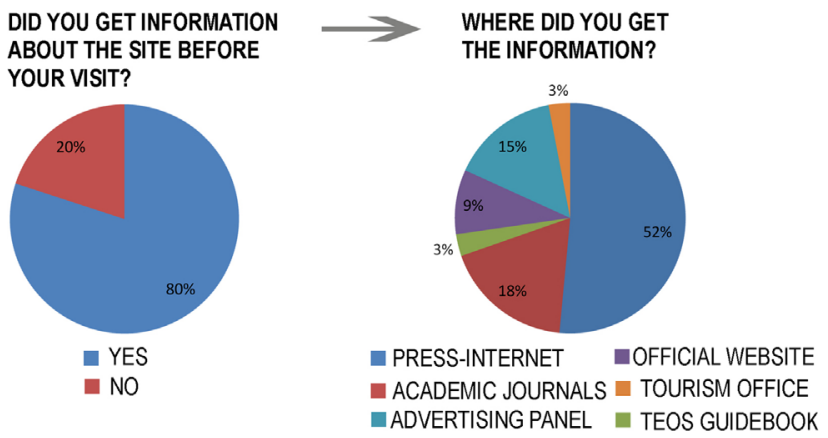

Figure 9. The results of visitors' survey at Teos archaeological site.

southern wall, on the north of parodos (stage entrance) and on the northern wall facing the stoa (roofed colonnade) (Figure 14). There is also an additional volume south-west of the building which is thought to be part of a defence wall which has been seen at the bouleuteria at Metropolis and Patara (Korkut 2006, 96; Öz 2006, 279). 


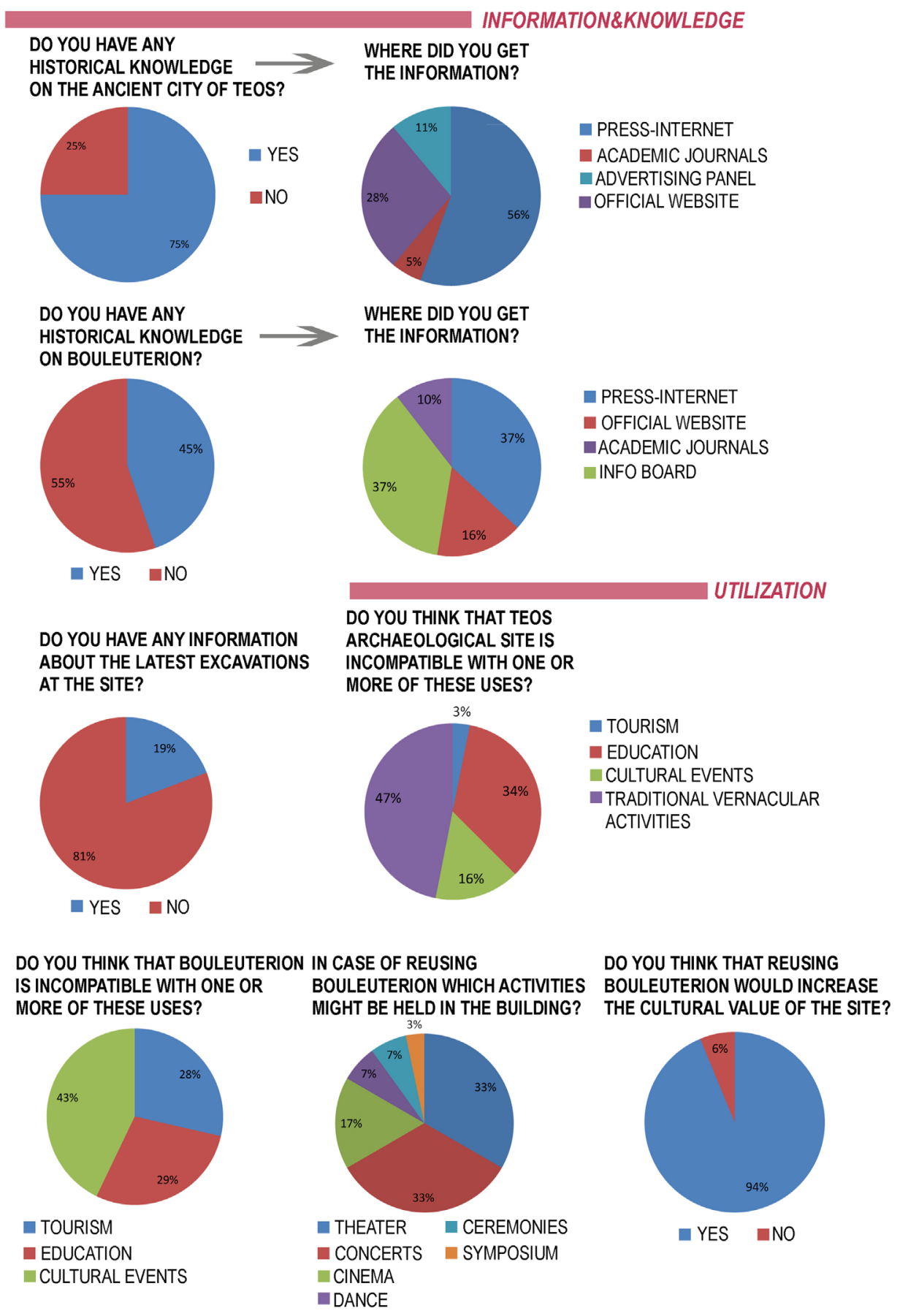

Figure 10. The results of visitors' survey at Teos archaeological site.

Today, remains of the cavea amount to only 17 rows of seats. It is divided by five stairs (klimakes) and four kerkides (wedge-shaped seating section). The profiled seating blocks are made of grey Teos marble and 14 rows are mostly preserved on the northern part. The stairs are made of grey Teos marble in width of 47 to $50 \mathrm{~cm}$, around $16 \mathrm{~cm}$ in height and $30 \mathrm{~cm}$ in 


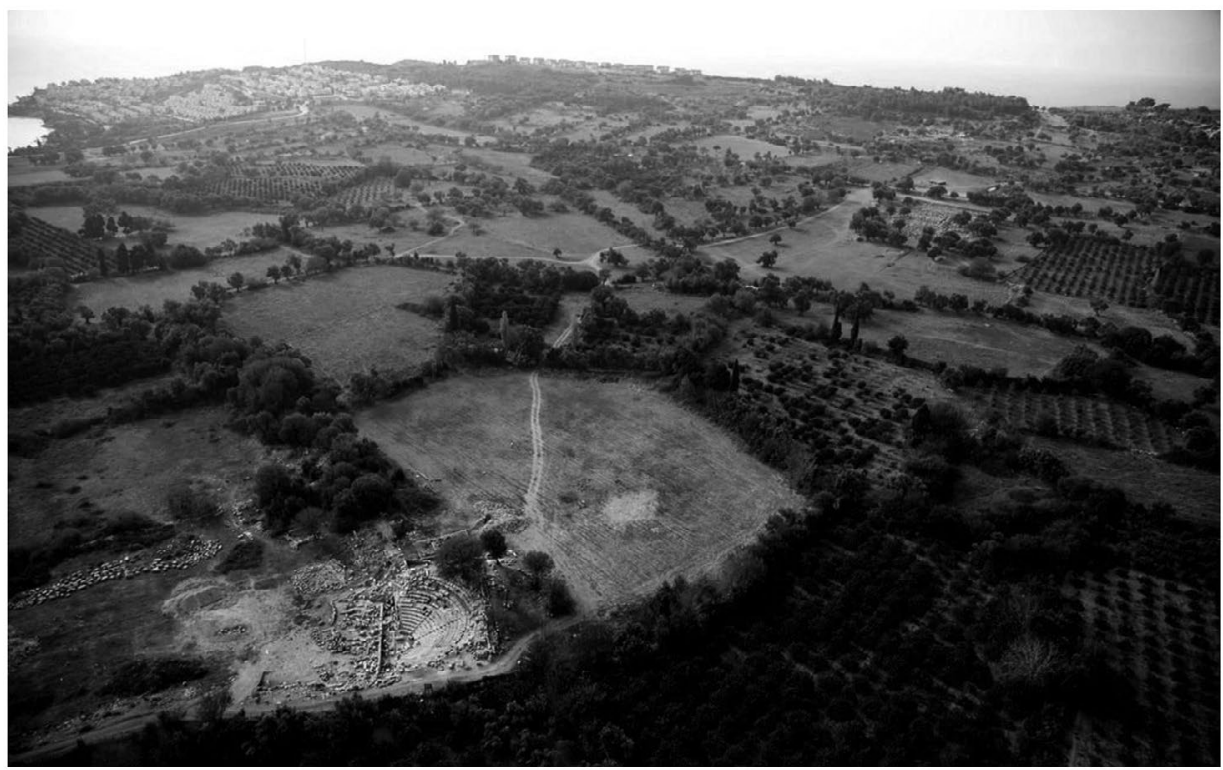

Figure 11. Aerial view of the bouleuterion and the Temple of Dionysos. Source: Teos Archaeological Project. Reprinted here by permission of Professor Dr Musa KADIOĞLU, Head of Teos Archaeological Project, Faculty of Languages, History and Geography, Department of Classical Archaeology, Ankara University.

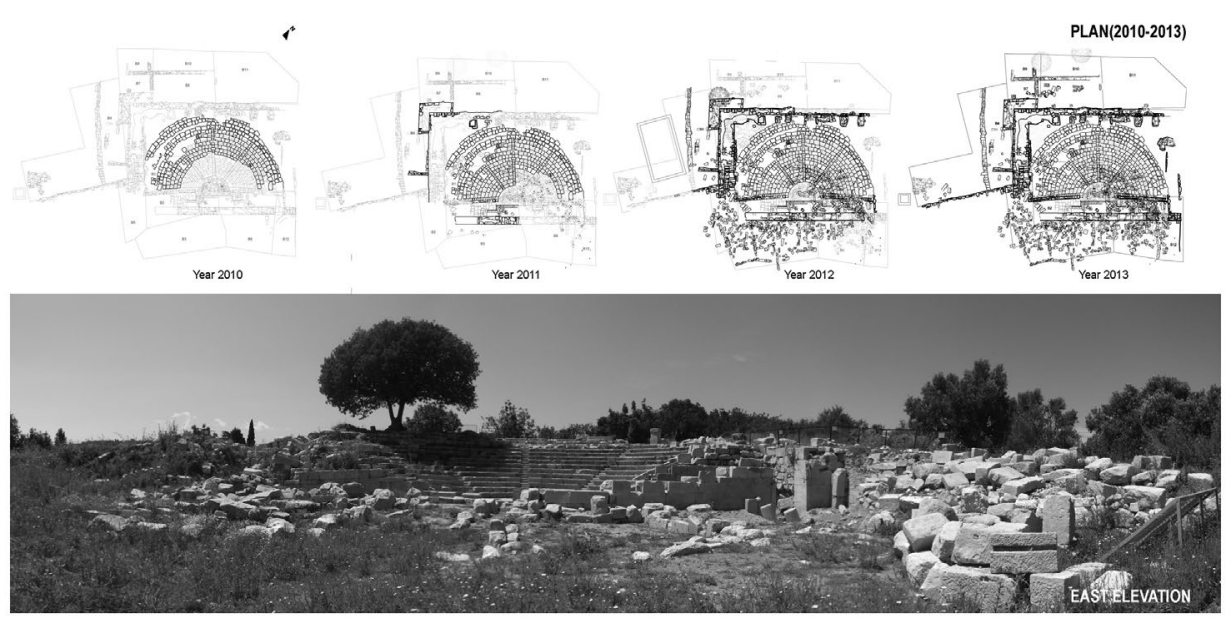

Figure 12. Measured plan drawings of the bouleuterion and the view from the east.

depth so that one seating row is equal to two steps in height (Kadıoğlu et al. 2013, 218). Analemmata walls (support walls for the seating area) were constructed in rectangular pseudo-isodomic technique with load bearing blocks $60 \mathrm{~cm}$ wide. The orchestra is $6.2 \mathrm{~m}$ in diameter extending more than a half-circle and the first row of seats begin at the orchestra level; however the finishing materials are not well preserved though we found a few broken pieces of marble. It was built in the opus sectile (decorated with inlaid materials) technique with 


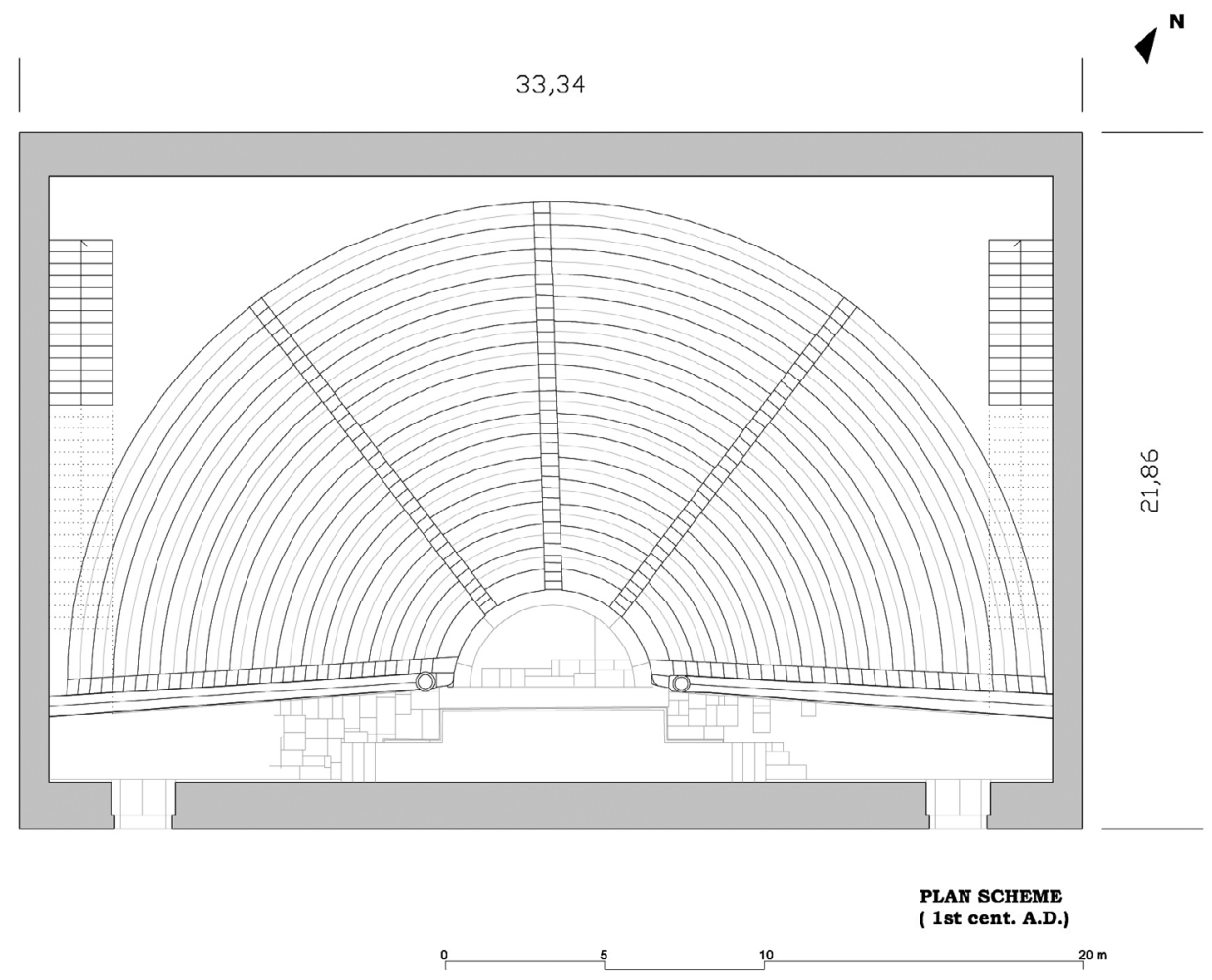

Figure 13. The plan of restitution of the bouleuterion.

different types of marble including Africano (Kadıoğlu 2015, 456). The pulpitum is located between the orchestra and skene wall (the wall of the structure behind the stage). It is made of grey Teos marble and its foundation and basement blocks are preserved as well as having three stairs on the south and two stairs on the north. In 2011, a bronze coin dating from the second century BCE was found under the second stair and a statue which is thought to date to the second century BCE was found in two pieces (Kadıoğlu et al. 2013, 219).

Evaluation of the bouleuterion's physical condition was made at the end of the excavation season in 2013. There is structural decay as a collapse on the southern wall and on the additional wall which was built later north of the parodos (stage entrance) and there are cracks on the building blocks. In addition, due to the dislocation of upper blocks, the structural problem occurs on the walls built in later times. Material decay was also observed in the building such as cracks, small cracks, features induced by material loss, detachments and biological formations (tree roots, plants, and lichen). There are small cracks, especially on the seating blocks and there are plants growing from the parts where there is material loss. Furthermore, a tree has grown on the upper level - on the southern part of the cavea, and tree roots were found on the west wall. Since the building is open to atmospheric conditions, biological formations, especially lichen is seen mostly on the stone blocks and on the orchestra as the features induced by material loss is found on the west wall. In general, the building is in good physical condition except the south wall and material deterioration is on average (Figure 15). 


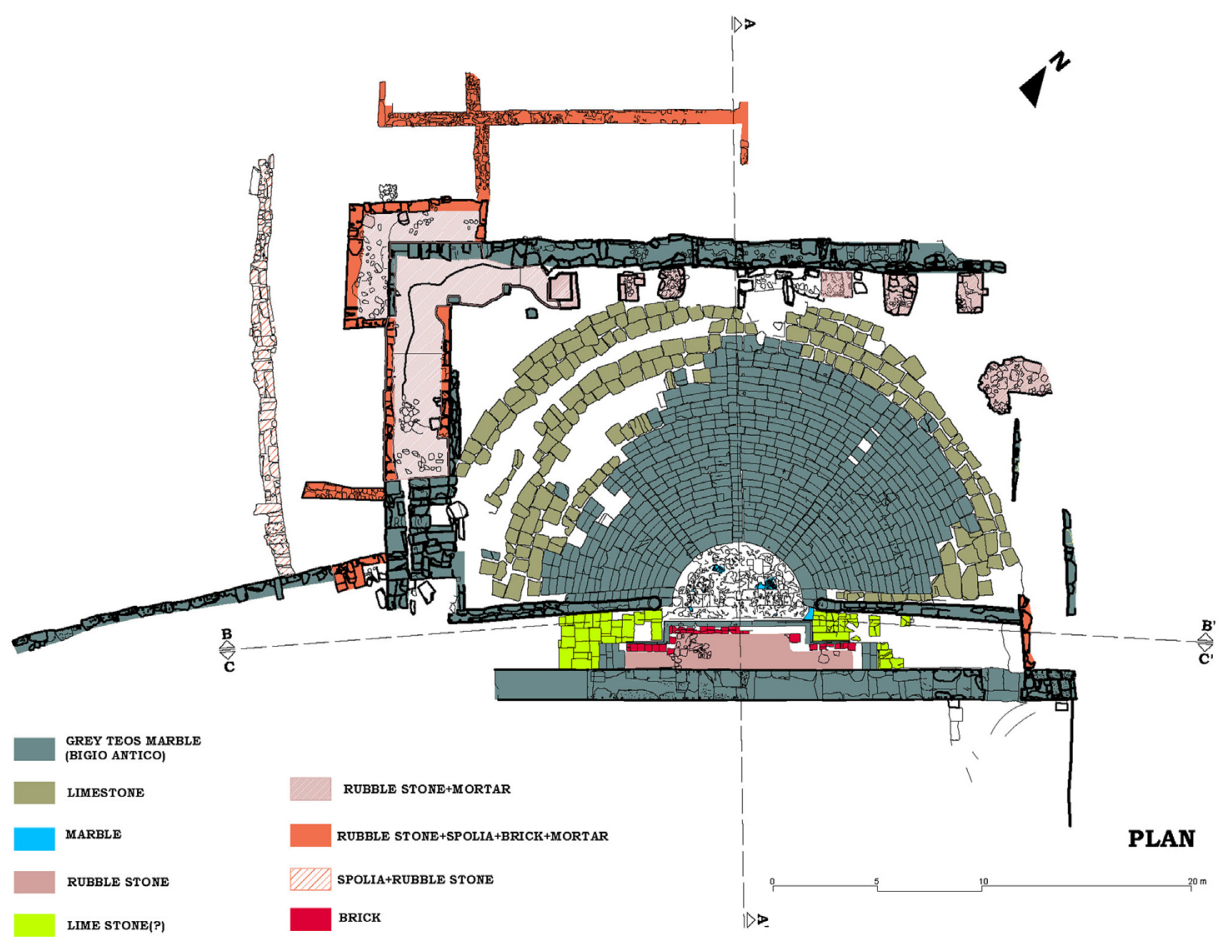

Figure 14. Mapping of the constructional materials of the bouleuterion.

Static and structural risks for the bouleuterion were studied with reference to the timeline of earthquakes in the region. There are numerous damages from ancient times as the idea of synoecism (uniting several towns under a single authority) following a population decrease, was proposed for Teos and Lebedos after the earthquake in 304 BCE (Rostovtzeff 1941, 155; Uz 1987, 57). An earthquake hit the ancient city in 17 CE when the thirteen lonian cities were totally destroyed (Emre et al. 2005, 54). Recently, earthquakes of medium intensity have occurred in Sığacık Gulf in 2005 where the fault lines in the NE-SW and NW-SE directions intersect in the area (Sözbilir et al. 2009). Today, Teos archaeological site is in the first degree seismic zone and the bouleuterion is intensely affected by earthquakes. ${ }^{18}$ The foundations of the building could not be seen because the excavations are still in progress around the building. Environmental factors such as climate and topography were also studied as they affect material decay. In the region, the dominant wind direction is NE and the wind speed is $3.5 \mathrm{~m} / \mathrm{s}$, the vaporisation increases and affects the resistance of the stones since the humidity is 64\% on average (Carbó et al. 2013, 110-116 and https://www.mgm.gov.tr/veridegerlendirme/il-ve-ilceler-istatistik.aspx?m=IZMIR). Damage caused by humans is quite low at the Teos archaeological site in comparison to other archaeological sites such as Izmir (Belge 2005, 111-117), Roman Ankara in Ulus (Mutlu 2012, 139-180) and Soli-Pompeiopolis in Mersin (Levent 2008, 107-122) which are located in urban conservation zones.

Sığacık is a small town with a low population except during the summer holiday season, which also coincides with excavations. However, there have been illegal excavations in the necropolis area on the south and on the west of the site and tumulus in and around Seferihisar (Kadıoğlu et al. 2011, 449; Kadıoğlu 2015, 455, 466). 

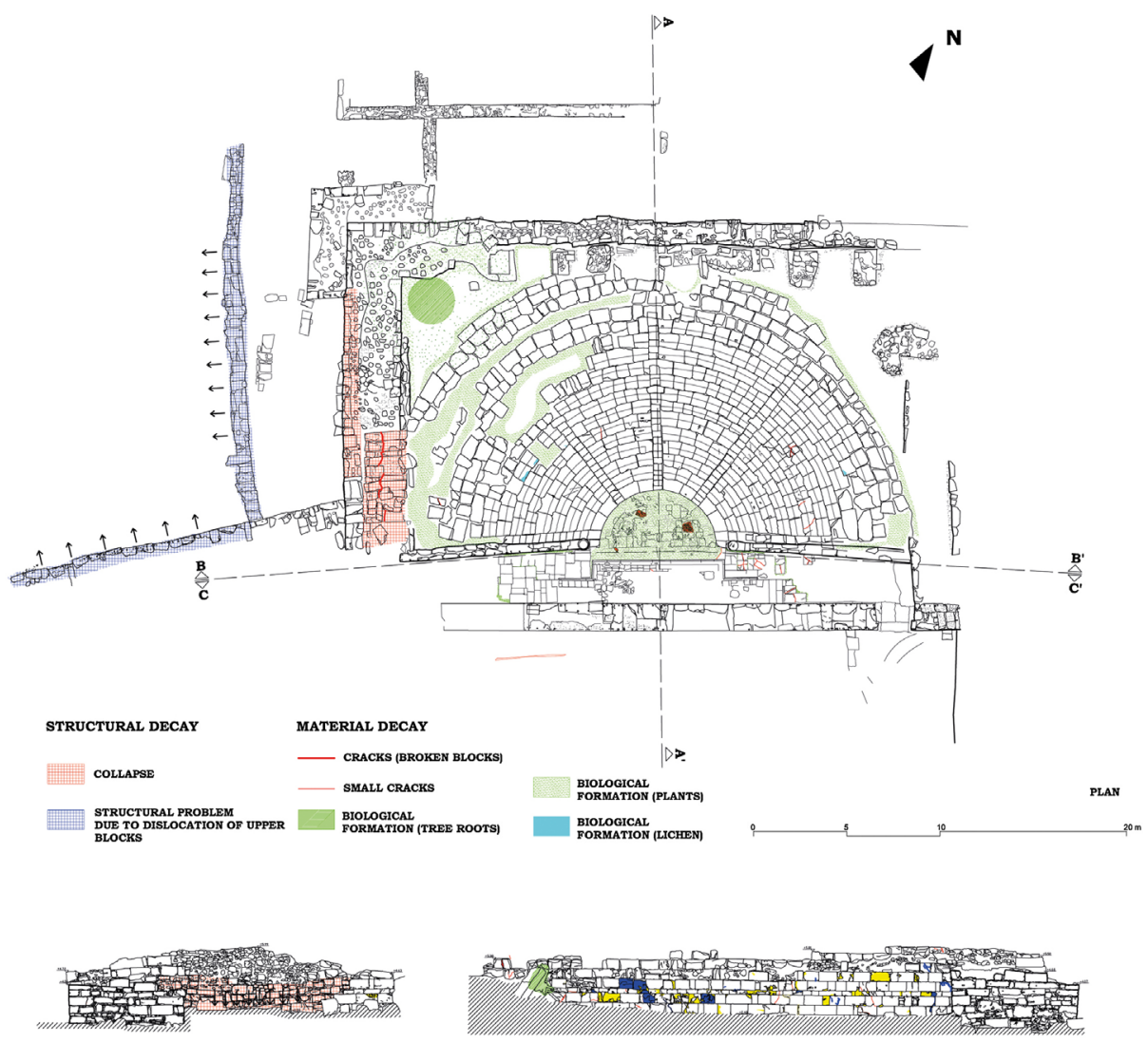

SOUTH ELEVATION

WEST ELEVATION
(BEFORE RESTORATION)

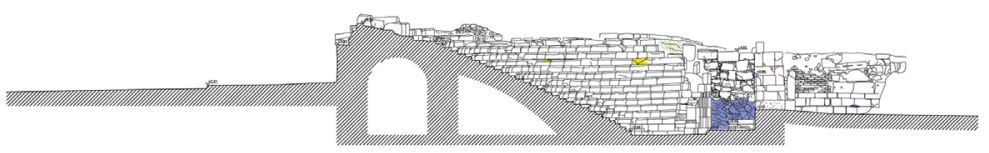

STRUCTURAL DECAY

SECTION AA:

$\downarrow \quad$ COLLAPSE
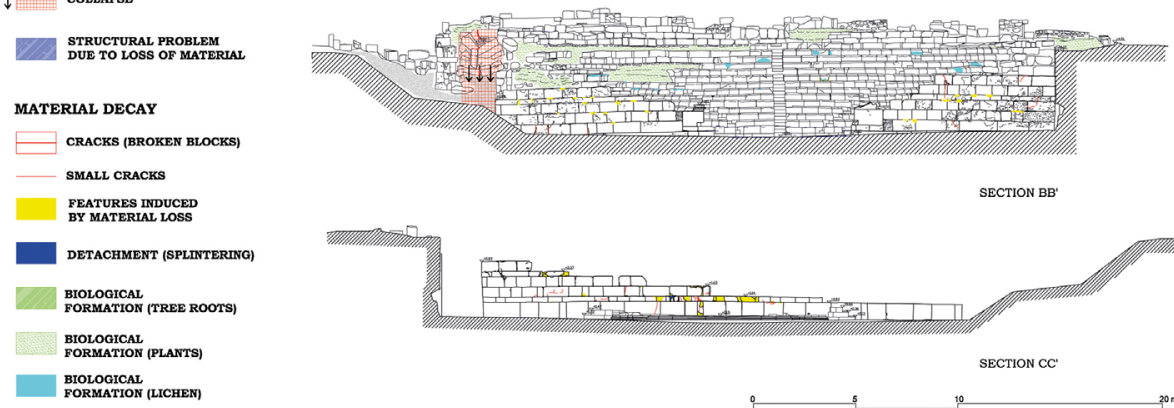

SECTION BB

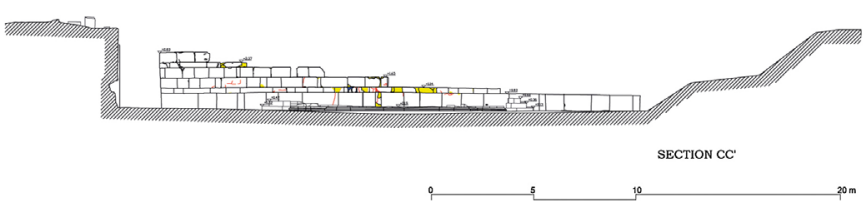

Figure 15. Mapping of structural and material decays of the bouleuterion. 


\section{Regional Socio-Economics and Intangible Cultural Heritage}

Seferihisar is an area of $38,583 \mathrm{~km}^{2}$ and the population is 34.761 . It has a second degree in the socio-economic development with the index of 1.5 in Turkey (Özaslan, Dinçer, and Özgür 2006, 15). ${ }^{19}$ The major economic sectors of Seferihisar are agriculture, forestry, hunting and fishing; secondary sectors are public services, social and private services; whereas the third sector includes trading activities, hotels and restaurants, and construction (Dinçer and Özaslan 2004). Mandarin, grape, artichoke, and other vegetables are the leading produce and fishing is also popular - the number of fish restaurants is high (see Appendix B: questionnaire for stakeholders of Teos Archaeological Site, Çalışkan 2015). In Seferihisar, distribution of green areas (including forests, parks etc. which are actively or passively used) is $3 \mathrm{~m}^{2}$ per capita whereas it is $245 \mathrm{~m}^{2}$ for the area archaeological sites (Izmir Development Agency 2013a).

Seferihisar is $47.1 \mathrm{~km}$ from the city centre of Izmir and $46.1 \mathrm{~km}$ from Izmir Adnan Menderes Airport. Main access to the Teos archaeological site can be had from the town centre of Seferihisar ( $6.5 \mathrm{~km}$ away) by small buses or by taxi. However, there is no direct transport to the site entrance today; visitors get off the bus and then have to walk 10 or 15 min down to the site entrance. There is no walkway for pedestrians and the hot summer weather may negatively affect older visitors or those with children. In summer, many tourists who stay in the hotels in Sığacık prefer to visit the site by bike and then walk through the features (Figure 16).

Cultural activities in Seferihisar are organised by the Municipality of Seferihisar. The most well-known is the mandarin festival ${ }^{20}$ that has been celebrated for 16 years in the bazaar of the town. Theatrical meetings (Tiyatrolar Buluşması in Turkish), supported by the Municipality of Seferihisar, Association of Science, Culture and Education on Research of Theatre Art, and the Community of Theatres of Turkey have been organised in the area with plays, concerts, and exhibitions mostly held in the Sığacık fortress in summers. ${ }^{21}$ These activities, also known as the Dionysian Arts, raise cultural awareness in the town. There is also a 'bazaar' set inside the fortress of Sığacık where there are historic houses and local people sell agricultural products and homemade traditional dishes every Sunday (Figure 17). It is known as a gastronomic pathway that visitors take inside to the fortress and these activities and events are considered to increase the socio-economic development of the town. (For more information on innovative programmes set for Seferihisar such as a Slow City, see Gündüz, Öner, and Knox 2016, 217). In addition, the Municipality of Seferihisar, the village cooperative, and Slow Food Teos organise events especially for women to support them economically where they can produce and sell local products in the bazaar held in Seferihisar and Sığacık and online. ${ }^{22}$

\section{Policy and Protection}

In the territory of Teos, there are five types of registered areas defined by the Ministry of Culture and Tourism, Superior Council of Real Estate Antiquities and Monuments. The Law on the Conservation of Cultural and Natural Property (Number 2863, 1983) defines an archaeological site as 'an area where man-made cultural and natural property converges as the product of various prehistoric to present civilizations, that is adequately defined by topography and homogenous, at the same time historically, archaeologically, scientifically, socially or technically valuable and exhibits partial structures'. According to regulations explained 


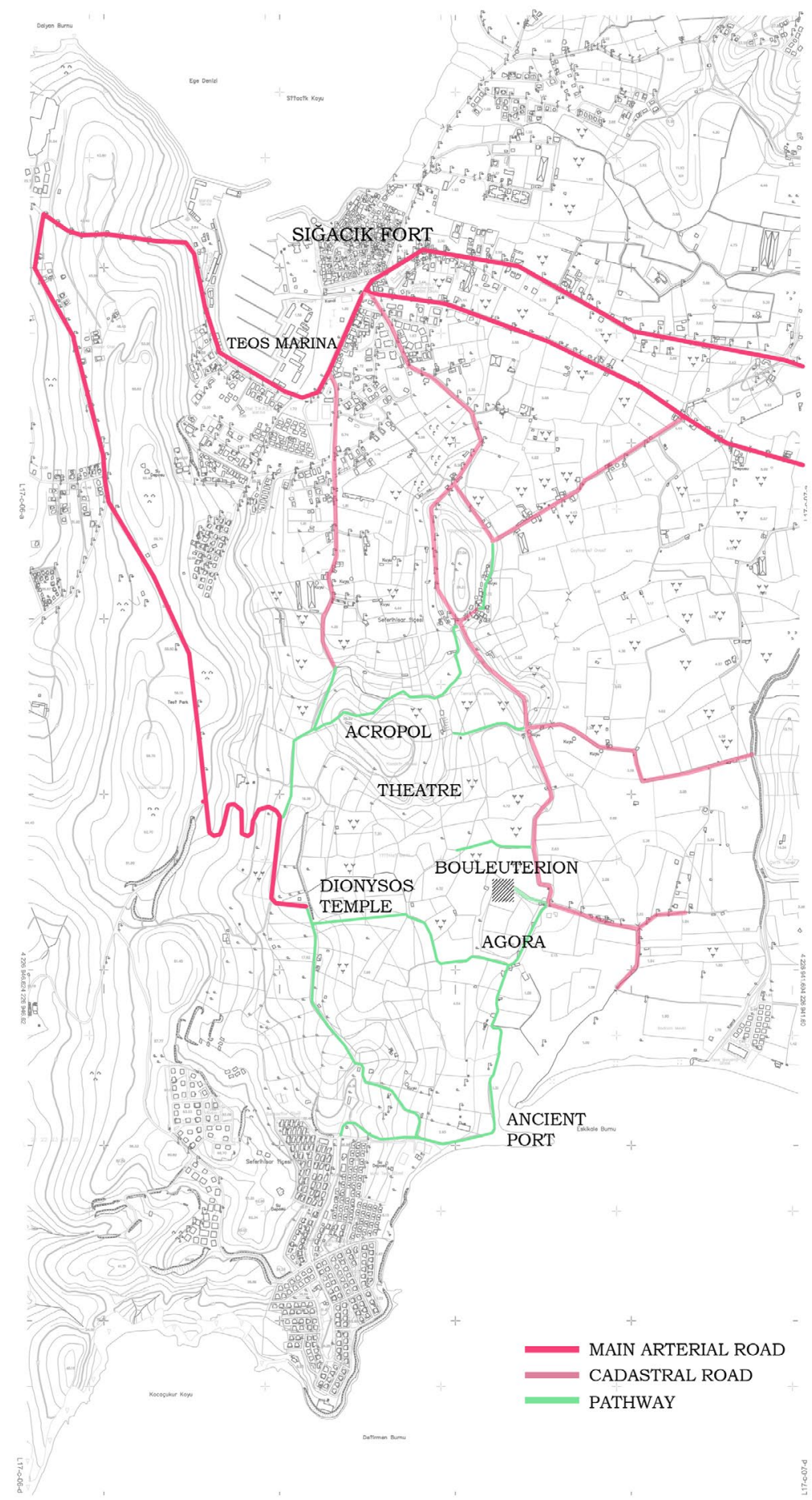

Figure 16. The routes of access in Teos archaeological site. 


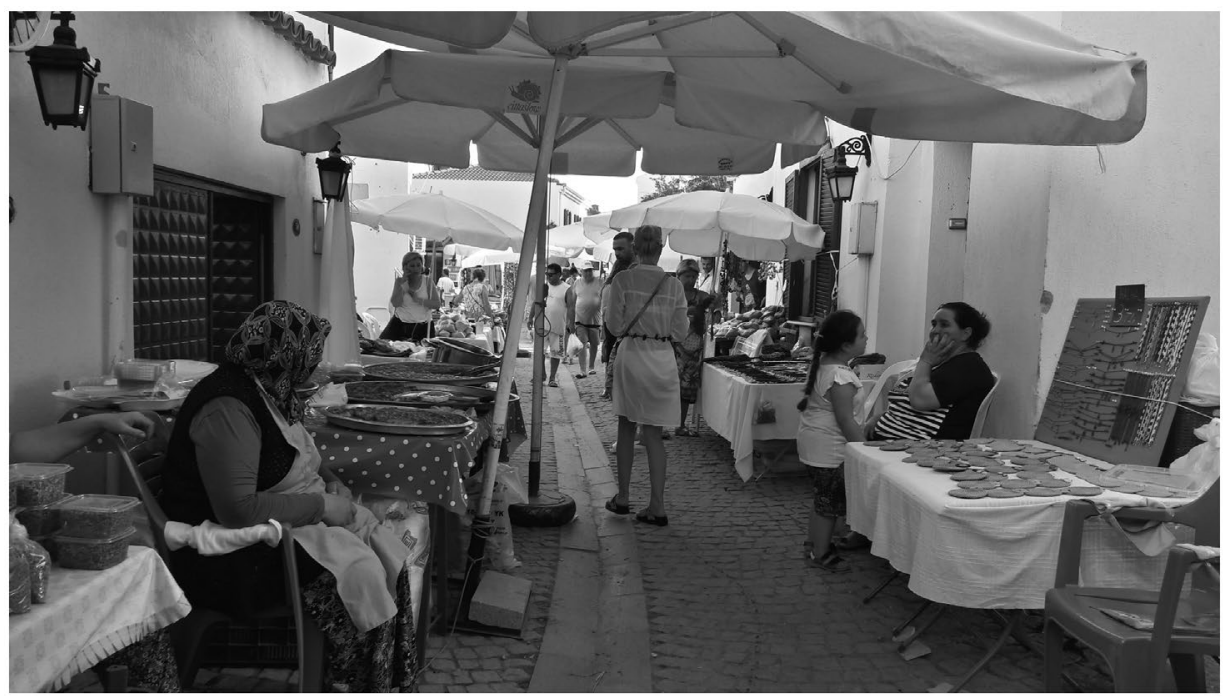

Figure 17. The bazaar in Sığacık Fort.

in the Resolution (658): 'archaeological sites, conditions for their conservation and utilisation' (1999), interventions in these areas must be approved by the consultancy of Izmir Regional Council of Conservation of Cultural Properties.

Since the bouleuterion is a cultural heritage asset in an archaeological site, the implementations have to be carried out according to the Law on the Conservation of Cultural and Natural Property (Number 2863) and Resolution (660) on the classification, conservation and maintenance of the immovable cultural properties (1999). For the utilisation of bouleuterion safety standards for performance buildings must be fulfilled. Regulations on 'new buildings' are declared in bylaws for construction that are approved by the municipalities and safety standards are clarified for each design. Regulations include the minimum number and the dimension of entrances according to the number of spectators, routes for fire escape, as well as a system of fire prevention (Regulation on the Fire Safety Measures for Buildings [2007]). These parameters will be discussed individually in order to define the real carrying capacity of the bouleuterion of Teos.

\section{A Study on the Carrying Capacity of Bouleuterion}

There are three types of carrying capacity suggested by the ATHENA Project Physical Carrying Capacity (PPC), Real Carrying Capacity (RCC) and Effective Carrying Capacity (ECC).

'Physical Carrying Capacity (PCC) is a rough estimate of the maximum number of visitors that an Ancient Theatre is actually able to support and the cavea, the orchestra pit and, on a partial and occasional way, the stage can be considered as suitable spaces for visitation activities. Real Carrying Capacity (RCC) is the second phase of the process: It deals with the limiting factors, reducing the amount of visitors obtained from the RCC calculation and it includes the analysis of the site conditions, and the physical, ecological (if necessary) and social factors. Effective Carrying Capacity (ECC) is the third analytical stage that deals with the managing capacity available of the corresponding site administration; managing 
capacity is not an easy task such as policy measures, legislation, infrastructure, facilities and equipment, staff, funding and motivation for heritage conservation (Viñals, Morant, and Monasterio 2013, 91, 92).

In this framework, the study on the carrying capacity of the bouleuterion focused on two types: Physical Carrying Capacity (PPC) and Real Carrying Capacity (RCC) since an estimation of the ECC could be made based on the structures which are already in use and managed for periodic performances. The PPC of the bouleuterion is calculated according to the physical condition of the building itself as the evaluation was made on the technical aspects which are the analysis of the site conditions, and the physical, social factors. Hereby, the cavea, orchestra, and pulpitum might be considered as safe zones for the users since they are stable and in good shape; however, the pulpitum and orchestra were evaluated as fragile areas with small cracks in a few of the seating blocks. Therefore, only if protective measures are taken for the orchestra, could the estimation for PPC be made.

The bouleuterion has a gross area of 408.6 and $235.4 \mathrm{~m}^{2}$ of it is calculated as the safe area for visitors including cavea, stairs, and orchestra. The World Tourism Organisation propose that $4 \mathrm{~m}^{2}$ might be available per person for dynamic activities which means that 52 visitors might visit the building at any time (World Tourism Organisation 2005; Viñals, Morant, and Monasterio 2013, 92). In the case of a performance, the seating capacity is calculated by dividing the seating area into $0.5 \mathrm{~m}^{2}$ (for more information on the visitors' psychological comfort and proxemics studies, see Hall 1966) and the area for the audience where the seating blocks are stable and in good shape is $145.3 \mathrm{~m}^{2}$, which means that 291 people could watch a performance inside the building (Figure 18).

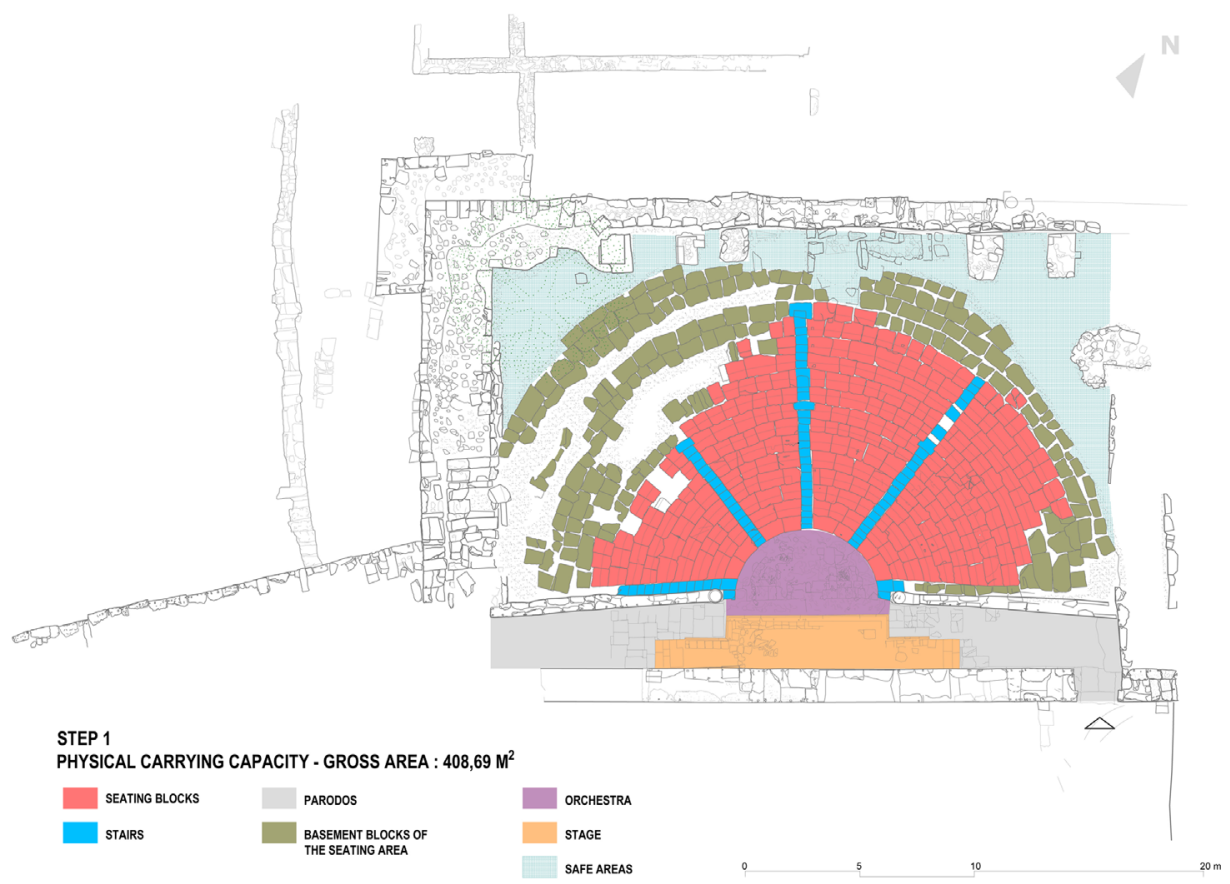

Figure 18. The mapping of physical carrying capacity of the bouleuterion. 
Estimation of the RCC for the bouleuterion is made by considering the cavea's not being an area for dynamic activities - visitors only sit and rest on the seating blocks. In other words, while it is impossible to control people's activities it would not be advisable to hold a rock concert here.

The pathway (stairs and stable areas for circulation) is in length of $69.4 \mathrm{~m}$ and when the diameter of $4 \mathrm{~m}^{2}$ is taken for the division; we can assume that 25 people can visit the building at any time. Further estimation should be made by the statistics of the number of visitors; especially for the sites which have been visited by tourists since the carrying capacity of the building might be lower than the number of visitors during the peak seasons. In this study, the exact number of visitors was unknown because the entrance building of Teos archaeological site was under construction during the study. Therefore, a prospective estimation was made according to the number of visitors seen during the survey in 2015 referring to the ratio of tourist arrivals by the statistics of the Ministry of Culture. It was seen that the average number of visitors per day was 204 on an optimistic day. Of the 50 individuals surveyed in August 2014, the bouleuterion was visited by $71 \%$ of the visitors, which means that 15 people visited the building per hour. In comparison to the RCC of the building above conditions of the building and the site fits well in (Figure 19). The Regulations for Fire Safety Measures define the limit as if the area is divided to $1 \mathrm{~m}^{2}$ for the capacity for modern buildings

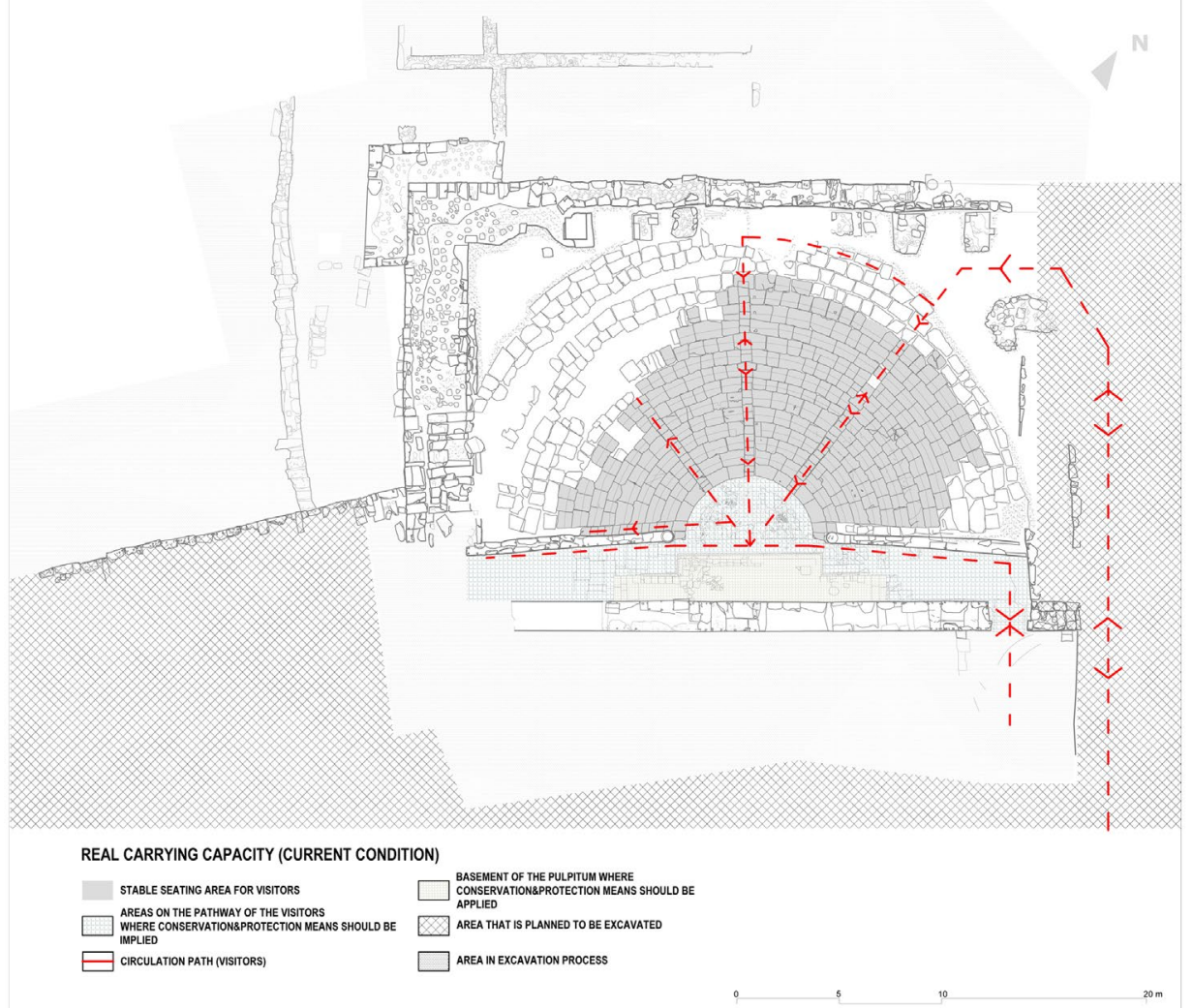

Figure 19. The mapping of real carrying capacity of the bouleuterion. 
(Binaların Yangından Korunması Hakkında Yönetmelik [Regulation on the Fire Safety Measures for Buildings] 2007). The bouleuterion has an area of $235.4 \mathrm{~m}^{2}$ in safe areas, so the regulation permits 235 people for the case of a performance. In addition, according to the current standards, there must be at least two entrances for access but today, the northern entrance is unearthed whereas southern entrance is still subsoil. This was estimated according to the Regulations on the Fire Safety Measures for buildings in Turkey. ${ }^{23}$

The study on the real carrying capacity of the bouleuterion shows that the building can be visited by 25 people at any time by turns for visiting on suggested pathway; however the building cannot carry the audience in case of an event since there are fragile areas to be conserved and consolidated whereas the unearthed parts including the analemmata, and the west and south walls are dangerous for the audience in the present conditions.

\section{Criteria and Proposals for Reusing the Bouleuterion}

In order to set a sustainable approach before reusing a historic building, the first priority should be considering the significance of the building and understanding the values both for the building and its environment - keeping a balance between conservation and public needs.

In this way, such an attitude would set the strengths, weaknesses, opportunities, and threats that have been addressed in this paper (Figure 20).

Throughout history, the bouleuterion of Teos has been affected by a multitude of geographic, climatic, political, economic, social, and cultural issues, and these issues continue. The cultural and contemporary values attributed to the building vary from different perspectives in aesthetic, historic, social, scientific, educational, functional, spiritual, and economic concerns. It is an ancient landmark of politics and administration though it was also used for grammar exams and ceremonies (Gneisz 1990) thus, it is defined as a multiple-use theatre (Izenour 1992) revealing its distinctive character architecturally in the network of Hellenistic - Roman ancient places of performance. Since the research and excavations are still in progress at the Teos archaeological site, it is important to keep in mind that the bouleuterion is a 'ruin' which is open to weathering and decay factors. Reusing it without a site management plan would increase its structural and material decay whereas its utilisation by monitoring the building's physical condition would increase public awareness and improve sharing knowledge in academic and public platforms. This was born out in the survey in which $90 \%$ of respondents answered 'yes' to the question 'do you think that utilisation of the bouleuterion would improve the cultural value of the site?' In previous events held in the bouleuterion, the organisers and the mayor gave opening speeches about the history of the building for the audience. The involvement of local people could be made by the organisations where they could improve their economic status by working for the organisation, selling products, renting their house in Sığacık for accommodation - house owners in Sığacık attended the certificate programme on hostelry that was organised by Seferihisar Municipality.

It was found that there are criteria and limits that are shaped by the carrying capacity of the bouleuterion; it is a 'ruin' open to weathering decay factors and has structural problems that might be dangerous for an event audience and it currently cannot be used for performances as it is still in the excavation process. Therefore, the initial use of the bouleuterion should be limited to passing touristic visits as the management of the site is the essential 
STRENGHTS

Bouleuterion is

- well-preserved

- has distinctive character as

being an ancient place of per-

formance

- has historical evidence that shows the identity of the build-

ing

has three construction phases unique to their construction techniques and terials

- seating blocks are - missing seating blocks and

stable and in good stair

W shape that can accom- - few seating blocks have smal

ऽ modate 291 people

- stairs are stable and in

good shape

嵌 - stable and in good

physical condition

- preserved at the basement level

ㄴ - construction technique and materials are visible

$\infty \quad$ - built in opus sectile s with africano marble

- in parodos limestone

finishing is used and

농

- south and west wall is unearthed

- both of them show different construction

periods

-skene wall is partially preserved

- both of them are par-

tially preserved

- both of them are stable

\section{WEAKNESSES}

the excavations held in and around the building is in process southern entrance and east wall is still earthed that the access to the building is problematic

cavea gets much sun light because of its orientation
- most of architectural elements are missing

orchestra is very fragile and there are cracks on marbles

in parodos, there are small racks

decay on material including small cracks

on the south wall, evidence of an earthquake is detected

structural decay due to loss of

architectural elements

- loss of blocks on the upper parts

- small cracks

- material deterioration due to

weathering agents

OPPORTUNITIES

THREATS

the building and around would - environmental factors of be resarched and excavated damage

that the knowledge on the build- - anthropological factors of ing (architecture and objects of damage (tourism growth)

aill be improved

the building might be used for contemporary performance activies.

- might be used by visitors and audience

issing seating blocks and stairs are dangerous for visitors

deterioration due to weathering agents

- tree roots maybe cause structural decay

- might be used as a base for stages in future

might be used as a base stages in future

- deterioration due to weathering agents

- might be intervened for the - deterioration due to weathaccess for visitors and audience

ering agents

material decay may occur due to visitor's flow

might be conserved and consolidated

- deterioration due to weathering agents

fallen blocks near the skene - earthquake and expansionwall might be used for anastylo- al loads might cause de-

struction

fallen blocks near might be used for anastylosis

deterioration due to weathering agents
Bouleuterion is

点 - is the most preserved structure at the site

- is located far from anthropological risks due to traffic

pollution, vandalism etc.

is in excavation process

- \%75 of visitors think that it

is easily accessible at the site he site entrance (visitors' path)

is surrounded by parcels be-

longing to private owners

there is no fire prevention

$\% 43$ of the visitors do not have

a historical knowledge on the

building

总

(1) time line of the ancient city will be damage

earthquake and expansionloads might cause destruction

- management plan for the con- damage

servation and utilization of the

sulding might be prepared.

as long as the conservation as-

pects are solved, ancient theater

and bouleuterion might be used

as 'venue' for performances

$\% 93$ of the visitors think that re-

using Bouleuterion would im-

prove the cultural value of the site

Bouleuterion is

- perceived as a cultural property

- is a spot for visitors

- is located close to the

zo urban settlement

- is on the route for cyclers

ㅍ - is on the route of trekking

w sports including Çeşme Pen-

insula

$\Xi \quad$ - has been used for cultura

events

- is perceived as having high

potential to be reused for

cultural events

-is located near to the acco-

modation and service facili-

ties

public access is problematic transportation to the entrance of

the site

-entrance building has not been pened officially

- lack of historical knowledge on

the building

interview with the stakeholders

show that local people do not have any interest at the site; in

contrary they think that the site is

source of trouble because of the restrictions since it is 1st degree archaeological site

management plan for the site - anthropological factors of might be prepared considering damage

the values in the region

as long as the conservation as-

pects are solved, ancient theater

and bouleuterion might be used

s 'venue' for performances serv-

ing the region

Figure 20. SWOT analysis of the bouleuterion. 
concern in present conditions. In these circumstances, the survey on bouleuterion that includes long-term and short-term physical interventions in reference to the mapping of structural and material decays are as follows:

- Setting up a management plan for the Teos archaeological site to improve public understanding of the site, to promote the site image by guaranteeing high standards for visitors and spectators and to manage safety issues.

- Preparation of a conservation project for the bouleuterion since it is under the risk of environmental factors whereas conservation measures must respect the aesthetic, historic, and scientific integrity.

- Intervention on the building must be based on sufficient documentation where all criteria, steps, activities, actions, and skills should be divided into long temporal sequences of alterations depending on the wear and tear and deterioration process on the structure.

- Research on the building's acoustic quality should be made according to its virtual reconstruction so as to improve the conditions for its future utilisation.

- Multidisciplinary work is needed for sharing the knowledge among the scientific community, European Network of Ancient Places of Performance (https://www.uia.org/s/ or/en/1100060652) and the public.

\section{Intervention Proposals for the Short-Term}

- Structural and physicochemical analysis of the building.

- Removing the broken blocks on the parts in critical condition (the collapse on the south wall) in order to check the condition of the wall and foundations by reconstruction using original materials.

- Applying removable support structures under the wall on the north of the parodos in order to prevent collapse.

- The consolidation of the original materials in the orchestra and pulpitum, integration with new materials which are compatible and removable might be implemented.

- Removing the plants, consolidation of the broken pieces of the seating blocks and stairs in order to create safe and stable areas in the cavea.

- Placing wires for safety next to the analemma walls that are dangerous for visitors.

- The consolidation of the pulpitum where the light modular structure might be applied in case of an event.

Socio-economic and intangible aspects in Seferihisar show that the associations and local authorities are the entrepreneurs for the promotion of the Teos archaeological site; however, according to interviews with stakeholders (Çalışkan 2015), local people do not participate in the cultural events which are held at the site, the majority of attendees are tourists. In addition, participation of the local people in the festivals and concerts held in Sığacık is quite low according to the Izmir Development Agency's Report (2014-2023 İzmir Bölge Planı Illçe Toplantıları, Seferihisar Raporu, IZKA [Development Agency of Izmir] Report [2013a] and [2013b]). ${ }^{24}$ Therefore, we can surmise that aids to understanding and interpretation of the cultural and natural properties in the area are inadequate and information instruments such as cultural tourism agencies and online cultural media are not used efficiently; educational tools are not used by the young people who live in Sığacık and Seferihisar according to the 
survey. It is true that locals do not attend the cultural activities unless they can earn money from these events and festivals. It is also related to the local culture and the types of events that locals prefer to attend. Therefore, it is recommended to:

- Set up a managerial unit by the Municipality of Seferihisar for educational purposes, which collaborates with teachers in local schools; with sociologists and trainers to share knowledge and to increase awareness for cultural and natural properties in the region

- Support professional enterprise for the management of cultural events such as IKSEV (Association for Culture Arts and Education of Izmir) since they organise concerts and festivals in Ephesus so that the demand for cultural activities would increase.

- Set up a 'model' for the intersection of the network of activities with the network of venues in the area so that the cultural events would be held in different cultural heritage places/spaces; for example Sığacık Fortress, bouleuterion and the ancient theatre would be the venues.

- Utilise the Teos archaeological site as the'venue'for the mandarin festival since the site is also a natural property with its rich fauna and flora. In addition, since the architectural remains are in the excavation process, the assignation of the theatres might organise events at the site in proper open areas.

- To educate young people and train personnel for the services of tourism; accommodation, shops, and restaurants in the region.

\section{Conclusion}

This study aimed to propose a model by putting the relevant data entirely in regard to the structure and the site before taking any intervention to reuse an ancient place of performance which is still in the process of being excavated. The model is an integration of analyses inspired by the ATHENA Project ${ }^{25}$ and Burra Charter Process (ICOMOS 2013) as a preliminary study that would supply the policies and strategies for the management of archaeological sites. Hereby, the real carrying capacity which has been evaluated according to the physical carrying capacity of the building and contributes to the significance of the site sets the structure for future interventions. While 'reusing' the site would increase the local people's awareness of the archaeological heritage and socio-economic development of the region. This study on the carrying capacity deals with touristic visits and audiences for future performances. The utilisation of the site and bouleuterion would enhance the site and the building (in the framework of a management plan) by the local people's involvement since it is defined as a cultural cluster and socio-economic data was collected because the bouleuterion is not an isolated object. It should be noted that feedback from the survey of visitors and interviews with stakeholders has been the main data for the proposed socio-economic aspects. Reusing the bouleuterion could not be fully assessed in the scheme of the local economy since the site is still under excavation.

Therefore, this study recommends action according to a SWOT analysis and assessment of the real carrying capacity of the ancient structure whereas further research on the effective carrying capacity should be conducted as if the site is in use and managed via feedback from visitors, stakeholders, users and personnel that would improve the quality of visits where the socio-economic and intangible aspects are considered as opportunities. 


\section{Notes}

1. In Turkish at http://seferihisar.bel.tr/tum-haberler/769-2-bin-500-yil-sonra-teosta-yenidensanat. html.

2. https://search.coe.int/cm/Pages/result_details.aspx?ObjectID=090000168052543f.

3. http://cordis.europa.eu/result/rcn/158866_en.html.

4. http://cordis.europa.eu/project/rcn/68732_en.html.

5. http://cordis.europa.eu/project/rcn/45528_en.html.

6. http://www.dream.unipa.it/dream/11/index_eng.html.

7. http://www.euromedheritage.net/intern.cfm?menulD=12\&submenulD=13\&idproject $=41$.

8. http://www.teosarkeoloji.com/hellenistik-sur-1.

9. See http://www.teosarkeoloji.com/teos for information in Turkish.

10. Resolution 658: archaeological sites, conditions for their conservation and utilisation, see the website in Turkish: http://teftis.kulturturizm.gov.tr/TR,14329/658-nolu-ilke-karari-arkeolojiksitlerkoruma-ve-kullan-.html. There are three types of protection for archaeological sites according to Resolution 658: 'archaeological sites, conditions for their conservation and utilisation' which is under the Law on the Conservation of the Cultural and Natural Properties (2868) in Turkey; first degree includes the sites which are definitely protected except for scientific excavations; second degree includes the sites which are protected where the regional conservation council approves the conditions of the protection and utilisation at the site; third degree includes the archaeological sites where the new regulations can be approved according to the conservation and protection decisions on the conservation plan. Conservation site is defined as 'cities and remains of cities that are product of various prehistoric to present civilizations that reflect the social, economic, architectural a.s. characteristics of the respective period' (Definitions and abbreviations, Article 3, (3)) whereas the 'natural site' is defined as 'shall refer to all assets on the ground, under the ground or under the water pertaining to geological periods, prehistoric periods until present time, that are of unique kind or require protection due to their characteristics and beauty' (Definitions and abbreviations, Article 3, (2) in law on the conservation of the cultural and natural properties, see the webpage: http://www. kulturvarliklari.gov.tr/TR,43249/law-on-the-conservation-of-cultural-and-natural-propert-. html).

11. http://www.cittaslow.org/.

12. https://www.slowfood.com/.

13. http://yavasyasa.com/.

14. http://seferihisar.bel.tr/en/.

15. http://www.dogadernegi.org/en/.

16. http://www.tr.undp.org/content/turkey/en/home/presscenter/articles/2013/10/03/teosancient-city-mashes-to-be-protected.html.

17. http://www.teosarkeoloji.com/multimedia/Teos_Rehber_Guide.pdf.

18. For the earthquake zoning map index of Turkey, see the website: http://www.deprem.gov.tr/ en/Category/earthquake-zoning-map-96531.

19. For more information on the SEDI Rankings in Turkey, see: http://www-sre.wu.ac.at/ersa/ ersaconfs/ersa06/papers/858.pdf.

20. http://seferihisar.bel.tr/en/welcome-to-the-festival-of-vitamin-c-of-seferihisar/.

21. Musical Paradise in Seferihisar 2017, http://seferihisar.bel.tr/en/musical-paradise-in-seferihisar/.

22. https://seferipazar.com/ and Traditional Soup Making Atelier http://seferihisar.bel.tr/en/ traditional-soup-making-atelier/.

23. http://www.resmigazete.gov.tr/eskiler/2007/12/20071219-2.htm.

24. http://www.izka.org.tr/files/planlama/3_ilce_calismalari/2014_2023/seferihisar/2014_2023_ ilce_ozet_raporu_seferihisar.pdf.

25. http://www.euromedheritage.net/intern.cfm?menulD=12\&submenulD=13\&idproject=41. 


\section{Acknowledgements}

This study was carried out by the author in compliance with the Master Thesis entitled 'A Study in Reusing Bouleuterion of Teos', supervised by Dr. Fuat Gökçe in the Department of Restoration, Middle East Technical University and completed in 2015. Drawings of the bouleuterion were made by the author during site work in 2012 and 2013. The author would like to thank her supervisor Dr. Fuat Gökçe for his contributions and Prof. Dr. Musa Kadıoğlu for his technical support at the site.

\section{Disclosure Statement}

No potential conflict of interest was reported by the author.

\section{Notes on Contributor}

Merve Çalışkan is an architect (MS in Restoration) and $\mathrm{PhD}$ student in the Department of Architectural Restoration, İzmir Institute of Technology. Experienced of the conservation, survey and documentation works held in Archaeological Sites of Teos and Sagalassos, she currently works in the Metropolitan Municipality of Izmir, in charge of archaeological and historical assets' conservation, restoration and presentation. Her research interest lies on the methods for the integration of the archaeological assets with the current urban life in urban renewal areas.

\section{References}

Aktüre, Z. 1995. "Guidelines for Future Models of Conservation and Utilization of the Theatre of Ephesos." MS diss., Middle East Technical University.

Akurgal, E. 2014. Anadolu Uygarlıkları. Ankara: Phoenix Yayınevi.

Altınöz, B. G., Ş. N Güçhan, Ö. Bakırer, and Y. Ayhan. 2011. "An Introduction to Processes and Terminology on the Conservation of Cultural Properties in Turkey." International Conference on Seismic Protection of Cultural Heritage, Antalya.

Bean, G. E. 1979. Aegean Turkey: An Archaeological Guide. 2nd ed. London: John Murray.

Belge, B. 2005. “Urban Archaeological Issues and Resources in Izmir Historic City Centre: An Exploratory Case Study." PhD diss., Middle East Technical University.

Béquignon, Y., and A. Laumonier. 1925. “Fouilles de Téos (1924)." Bulletin de correspondance hellénique 49: 281-321.

Çalışkan, M. 2015. "A Study on Reusing Bouleuteron of Teos." MS diss., Middle East Technical University.

Carbó, M. T. D., F. J. Vidal, F. Fantini, A. Benlloch, A. Insa, S. L. Ortega, M. J. V. Blasco, et al. 2011. “Athena Project: Guidelines for the Sustainable Use of Ancient Theaters." Arché 6: 119-126. Instituto Universitario de Restauración del Patrimonio de la UPV. http://www.irp.webs.upv.es/documents/ arche_article_187.pdf.

Carbó, M. T. D., F. J. Vidal, F. Fantini, A. Benlloch, A. Insa, S. L. Ortega, M. J. V. Blasco, et al. 2013. ATHENA Project: Ancient Theaters Enhancement for New Actualities, Prototype of Management Plan for Enhancement of New Actualities. Valencia: General de Ediciones de Arquitectura.

Council of Europe. 1995. "Declaration of Segesta, Adopted at the Conclusion of the Conference: Protection and Use of Ancient Theaters." Segesta, September 17-20. http://conservacion.inah.gob. $\mathrm{mx} /$ normativa/wp-content/uploads/Documento118.pdf.

Council of Europe. 1997. "The Verona Charter on the Use of Ancient Places of Performance." International Colloquy, Verona, August. doi:10.1179/135050399793138572.

Dinçer B., and M.Özaslan 2004. İç̧elerin sosyo-ekonomik gelişmişlik sıralaması araştırması. Devlet Planlama Teşkilatı. Accessed August 16, 2014. http://www.kalkinma.gov.tr/Lists/Yaynlar/Attachments/299/ilce. pdf

Emre Ö., S. Özalp, A. Doğan, V. Özaksoy, C. Yıldırım, and F. Göktaş. 2005. Izmir Yakın Çevresinin Diri Fayları ve Deprem Potansiyelleri. MTA Rapor No:10754. Maden Tetkik ve Arama Enstitüsü, Jeoloji Etütleri 
Dairesi. Accessed 23 August, 2017. http://www.mta.gov.tr/v3.0/sayfalar/bilgi-merkezi/deprem/pdf/ izmir_rapor.pdf

Feilden, Bernard M. 2003. Conservation of Historic Buildings. 3rd ed. Oxford: Architectural Press.

Feilden, B. M., and J. Jokilehto. 1993. Management Guidelines for World Cultural Heritage Sites. 1st ed. Rome: ICCROM.

Gneisz, D. 1990. Das antike Rathaus: Das griechische Bouleuterion und die fruhromische Curia. Wien: Dissertationen der Universitat Wien.

Günday, R. 2006. "Ancient Theatres: Some Thoughts on the Preservation and Use in Our Day." In Management and Preservation of Archaeological Sites: 4th Bilateral Meeting of ICOMOS Turkey-ICOMOS Greece, April 29-May 2, 2002, Side (Antalya-Turkey), edited by Ahunbay Zeynep and İzmirligil Ülkü, 90-92. İstanbul: Siva Side Eğitim Kültür ve Sanat Vakfı.

Gündüz, C., A. C. Öner, and P. L. Knox. 2016. "Social Resilience in Aegean Slow Cities: Slow City Seferihisar." Universal Journal of Management 4 (4): 211-222. doi:10.13189/ujm.2016.040407.

Haddad, N. 2007. "Criteria for the Assessment of the Modern Use of Ancient Theatres and Odea." International Journal of Heritage Studies 13 (3): 265-280. doi:10.1080/13527250701228221.

Hall, T. 1966. The Hidden Dimension. New York: Anchor Books.

ICOMOS. (1964) 1965. "International Charter for the Conservation and Restoration of Monuments and Sites." First developed at the 2nd International Congress of Architects and Technicians of Historic Monuments, Venice. Accessed February 25, 2017. https://www.icomos.org/charters/venice_e.pdf

ICOMOS. 2003. "Charter- Principles for the Analysis, Conservation and Structural Restoration of Architectural Heritage (2003) Ratified by the ICOMOS 14th General Assembly in Victoria Falls, Zimbabwe." Accessed February 25, 2017. http://www.icomos.org/charters/structures_e.pdf

ICOMOS. 2013. "The Australia Burra Charter for Places of Cultural Significance." Adopted in 2013. Accessed February 25, 2017. http://australia.icomos.org/wp-content/uploads/The-Burra-Charter2013-Adopted-31.10.2013.pdf

Izenour, G. C. 1992. Roofed Theatres of Classical Antiquity. New Haven: Yale Press.

İzmir Development Agency. 2013a. "Report on the Sustainable Development Strategy of Urla-Karaburun Peninsula." [IZKA Urla-Çeşme-Karaburun Yarımadası Sürdürülebilir Kalkınma Stratejisi Raporu.] Accessed May 3, 2014. http://www.izmiriplanliyorum.org/static/upload/file/yarimada_kalkinma_ stratejisi_mevcut_durum_analizi.pdf

İzmir Development Agency. 2013b. "Seferihisar Report, the District Meetings of 2014-2023 İzmir Regional Plan." [2014-2023 İzmir Bölge Planı İçe Toplantıları, Seferihisar Raporu.] Accessed May 3, 2014. http://www.izka.org.tr/files/planlama/3_ilce_calismalari/2014_2023/seferihisar/2014_2023_ ilce_ozet_raporu_seferihisar.pdf

Kadıoğlu, M. 2015. "2012-2013 Teos Kazı Çalışmaları." In 36.Kazı Sonuçları Toplantısı. 3.Cilt, 437-472. Ankara: Kültür ve Turizm Bakanlığı.

Kadıoğlu, M., M. Adak, C. Özbil, S. H. Öztaner, R. T. Polat, and Y. Polat. 2013. "2011 Yılı Teos Kazı Çalışmaları." In 34.Kazı Sonuçları Toplantısı. 2.Cilt, 211-232. Ankara: Kültür ve Turizm Bakanlığı.

Kadıoğlu, M., C. Özbil, M. Kerschner, H. Ergin, S. Gülgönül, G. Yenice, Y. Polat, et al. 2016. "2014 Yılı Teos Kazı Çalışmaları." In 37.Kazı Sonuçları Toplantısı. 3.Cilt, 451-478. Ankara: Kültür ve Turizm Bakanlığı.

Kadıoğlu, M., C. Özbil, M. Adak, Ç. G. Güray, T. Polat, H. Ergin, R. T. Polat, et al. 2017. "2015 Yılı Teos Kazı Çalışmaları." In 38.Kazı Sonuçları Toplantısı. 2.Cilt, 485-508. Ankara: Kültür ve Turizm Bakanlığı.

Kadıoğlu, M., M. Adak, C. Özbil, D.Ö. Yalçın, and Y. Polat. 2011. "2010 Yılı Teos Kazı Raporu (Illk Sezon)". In 33. Kazı Sonuçları Toplantısı, 3. Cilt, 429-460. Ankara: Kültür ve Turizm Bakanlığı.

Kahraman, S. A., ed. 2011. Evliya Çelebi Seyahatnamesi(Günümüz Türkçesiyle). 9th book. Vol. 1, 142-413. İstanbul: Yapı Kredi Yayınları.

Korkut, T. 2006. "The Parliament Building of Patara." In Common Ground: Archaeology, Art, Science and Humanities. Proceedings of the XVIth International Congress of Classical Archaeology Boston, August 23-26, 2003, 93-97. Oxford: Oxbow Books.

"Law on the Conservation of Cultural and Natural Property." 1983. Law Number 2863, Published in Official Gazette on: 23/07/1983 Number 18113. Accessed July 1, 2017. http://www.kulturvarliklari. gov.tr/yazdir?531105DF9A42FFF5BEB9853A83022775

Levent, Y. S. 2008. “Conservation of Archaeological Sites in Urban Areas in Turkey: Soli-Pompeiopolis as a Case Study." PhD diss., Middle East Technical University. 
Mutlu, Ö. 2012. "Integration of the Roman Remains in Ulus Ankara within the Current Urban Context." MS diss., Middle East Technical University.

Öğün, B. 1965. “Teos Kazıları 1963.”In Türk Arkeoloji Dergisi, 13 (1): 115-121. Ankara: Ankara Üniversitesi Basımevi.

Öz, A. K. 2006. "Antik Dönem Meclis Binalarının Metropolis Örneğinde Araştırılması ve Korunması."PhD diss., Dokuz Eylül University.

Özaslan, M. B., B. Dinçer, and B. Özgür. 2006. "Regional Disparities and Territorial Indicators in Turkey: Socio-Economic Development Index (SEDI)." Accessed August 23, 2017. http://www-sre.wu-wien. ac.at/ersa/ersaconfs/ersa06/papers/858.pdf

Öztürk, A. 2006. "Reuse Problems Related to the Great Theather of Ephesus." In Management and Preservation of Archaeological Sites: 4th Bilateral Meeting of ICOMOS Turkey-ICOMOS Greece, April 29May 2, 2002, Side (Antalya-Turkey), edited by Ahunbay Zeynep and İzmirligil Ülkü, 94-96, İstanbul: Siva Side Eğitim Kültür ve Sanat Vakfı.

"Regulation on the Fire Safety Measures for Buildings." [Binaların Yangından Korunması Hakkında Yönetmelik.] 2007. Accessed August 23, 2017. http://www.resmigazete.gov.tr/ eskiler/2007/12/20071219-2.htm

"Resolution (660) on the Classification, Conservation and Maintenance of the Immovable Cultural Properties." [(660 nolu Illke Kararı) Taşınmaz Kültür Varlıklarının Gruplandırılması, Bakım ve Onarımları.] 1999. Accessed August 23, 2017. http://teftis.kulturturizm.gov.tr/TR,14330/660-nolu-ilke-kararitasinmaz-kultur-varliklarinin-grup-.html

Rostovtzeff, M. 1941. Social and Economic History of Hellenistic World. Oxford: Oxford University Press.

"Siracusa Charter for the Conservation, Fruition and Management of the Ancient Theatrical Architectures." 2005. 2nd International Conference: Teatri antichi nell'area del Mediterraneo, Siracusa, October 13-17, 2005.

Sözbilir, H., Ö. Sümer, B. Uzel, Y. Ersoy, F. Erkül, U. İnci, C. Helvacı, et al. 2009."17-20 Ekim 2005-Sığacık Körfezi (İzmir) depremlerinin sismik jeomorfolojisi ve bölgedeki gerilme alanları ile ilişkisi, Batı Anadolu." [17-20 October 2005 - The Relation of the Stress Field and the Seismic Geomorphology of the Earthquakes in the gulf of Sığacık (İzmir)]. Geological Bulletin of Turkey 52(2), pp. 219-235. Accessed August 23, 2017. http://www.geo.uu.nl/ forth/publications/Sozbilir_2009.pdf

Strabon. 2000. Geographika Antik Anadolu Cografyası, Kitap: XII-XIII-XIV. Translated by Adnan Pekman and edited by Nezih Başgelen. İstanbul: Arkeoloji ve Sanat Yayınları.

Strang, J. R. 2007. "The City of Dionysos: A Social and Historical Study of the lonian City of Teos." PhD diss., State University of New York at Buffalo.

"The Resolution (658): Archaeological Sites, Conditions for their Conservation and Utilization." [ 658 nolu Illke Kararı) Arkeolojik Sitler, Koruma ve Kullanma Koşulları.] 1999. Accessed August 23, 2017. http:// teftis.kulturturizm.gov.tr/TR,14329/658-nolu-ilke-karari-arkeolojik-sitler-koruma-ve-kullan-.html

The Society of Dilettanti. 1769. Antiquities of Ionia. Vol. I. London: Macmillan.

The Society of Dilettanti. 1881. Antiquities of Ionia. Vol. IV. London: Macmillan.

Tuna, N. 1997. "Teos Araştırmaları 1995." In 14. Araştırma Sonuçları Toplantısı, 1.Cilt, 219-233. Ankara: Kültür Bakanlığı.

Uz, D. M. 1987. “Teos'taki Dionysos Tapınağı.” PhD diss., Dokuz Eylül University.

Viñals, M. J., M. Morant, and P. A. Monasterio. 2013. "Key Issues in the Ancient Theatres Recreational Carrying Capacity Assessment Studies." In ATHENA Project: Ancient Theaters Enhancement for New Actualities, Prototype of Management Plan for Enhancement of New Actualities, edited by General de Ediciones de Arquitectura, 91. Valencia: General de Ediciones de Arquitectura.

World Tourism Organisation. 2005. Indicators of Sustainable Development for Tourism Destinations. Guidebook. Madrid:WTO. 